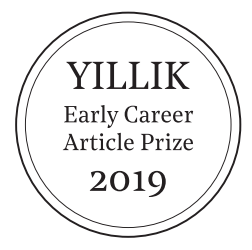

\title{
Silent Guardians of the Regime: The 'Lost' Police Stations of the Topkapı Palace
}

\author{
Nilay Özlü*
}

\begin{abstract}
This article examines the emergence of police stations as an architectural and institutional novelty that reflected the modernization and centralization of the Ottoman Empire during the nineteenth century. At the heart of this paper lies the Topkap1 Palace, the traditional residence of the Ottoman dynasty, which was abandoned by the imperial family in the nineteenth century and then took on new meanings and functions. The symbolic, religious, political, and historical significance of the Topkap1 Palace endured and new buildings and institutions were established within the precincts of the royal complex. Numerous police stations were also erected in the Topkapi Palace from the reign of Mahmud II (18o8-1839) onwards, which manifested the visibility and authority of the ruler and emphasized the changing military character of the state. Under the rule of Abdülhamid Il (1876-1909) the number of police stations within the royal complex amounted to ten, which underlines the importance attributed to the symbolic and physical protection of the Topkapı Palace. This article explores the ideological, urban, and architectural implications of these police stations, which reflected the public control mechanisms of the regime. Some of the police stations built during the reign of Abdülhamid II at strategic points of the Seraglio were later demolished without any reliable documentation, and this article brings together textual, visual, and architectural information on the emergence and destruction of these 'lost' police stations.
\end{abstract}

Keywords: Topkapı Palace, police stations, modernization, disciplinary mechanisms

\section{Rejimin Sessiz Bekçileri: Topkapı Sarayı'nın 'Kayıp' Karakolları}

\section{Özet}

Bu çalışma, Osmanlı İmparatorluğu'nda polis kuvvetlerinin kurulmasına paralel olarak, yeni bir yapı türü ve bir kontrol aygıtı olarak ortaya çıkan "karakol" yapılarını merkeze alır. On dokuzuncu yüzyılın askeri ve idari reformların bir yansıması olarak ele alınan karakollar, modernleşen devlet mekanizmalarının araçları olmalarının yanında, meşruiyet krizi yaşamakta olan son dönem padişahlarının da tebaaları üzerindeki otorite ve kontrolünü pekiştiren mimari ve görsel elemanlar olarak incelenmektedir. Bu makale, on dokuzuncu yüzyılda imparatorluğun yönetim merkezi ve hanedan ailesinin yerleşkesi olmaktan çıkarak, yeni anlamlar ve işlevler kazanan Topkapı Sarayı'na odaklanmakta ve II. Mahmud'dan (1808-1839) Il. Abdülhamid (18761909) döneminin sonuna kadar kadim sarayda inşa edilen on karakolun kapsamlı bir analizini sunmaktadır. Bu karakolların zaman içinde değişen mimari morfolojileri, dönemin başat ideolojisini ve mimari dilini yansıtmakta; bunun yanı sıra iktidarını sultanın görünürlüğü ve temsiliyeti üzerinden kurgulayan Osmanlı görsel ideolojisinin değişimini de göstermektedir. Ancak, Sarayburnu'nun en görünür noktalarına inşa edilen ve sultanın mutlak otoritesinin ve görünmez gözünün sembolü olan birtakım karakollar daha sonraki dönemlerde belgelenmeden yıkılmış, toplumsal hafızadan silinmiştir. Bu makale, Topkapı Sarayı'ndaki karakolların izini, arşiv belgeleri, kartpostallar, fotoğraflar, gravürler ve gazetelerden derlenen bilgiler üzerinden sürer.

Anahtar kelimeler: Topkapı Sarayı, polis karakolları, modernleşme, disiplin mekanizmaları

\footnotetext{
* Altınbas University, University of Oxford, nilay.ozlu@gmail.com

I would like to thank Irvin Cemil Schick, Nil Mustafa, and Baran Ungan for their contributions to this article, and Lauren Davis for proofreading the initial version of this paper. I am also grateful to K. Mehmet Kentel for his sincere help and attentive support throughout the publication process, and to the other editors and proofreader of the journal. Finally I would like to express my gratitude to two anonymous referees for their insightful suggestions.
} 
Two peculiar photographs (fig. 1a-1b) from the renowned Abdülhamid Il Albums depict the front and side elevation of a single story building, with captions in French and Ottoman Turkish. Both the French ("Corps de garde du Palais de TopKapou") and the Turkish ("Topkap1 Sarayında kâin Karakolhane-i Hümayun") captions confirm that these photographs belong to a certain police station that was located in the Topkapı Palace. However, there is no information regarding the name or location of this edifice. Considering that there currently is no building that resembles the one shown on the photographs within the precincts of the Topkapi Palace, I decided to investigate this issue more closely in order to shed light on this mysterious police station and find its location within the royal complex.
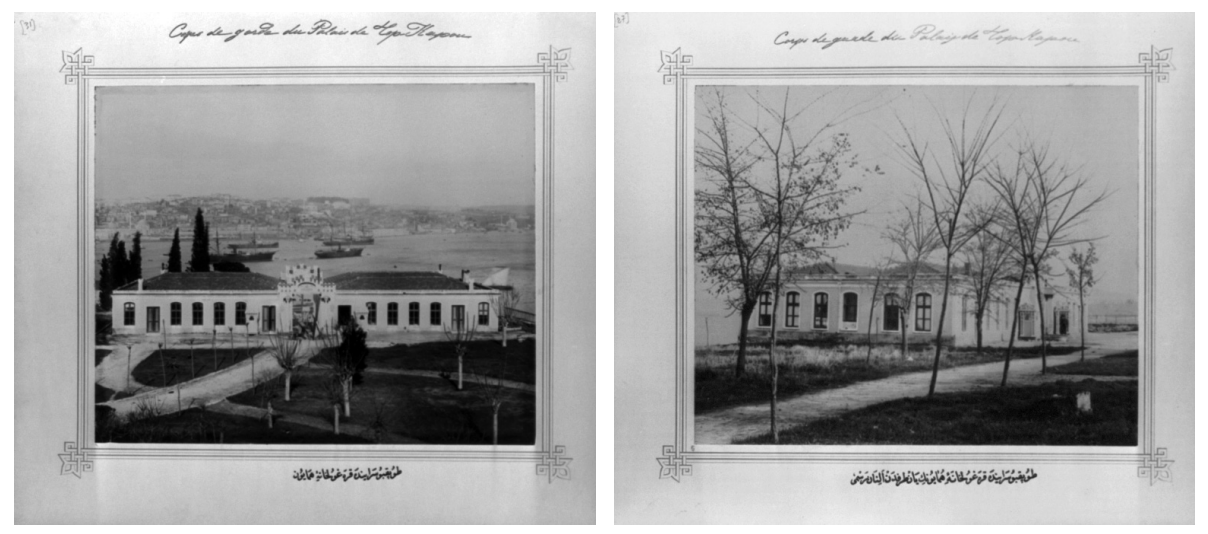

By spotting some of the existing monuments on the photographs, marking their locations on contemporary maps and by taking cross bearings, it was possible to identify the approximate geographical location of the police station, which happened to be at the tip of the Historic Peninsula. A close-up investigation of a series of Seraglio panoramas helped me to identify the exact location of this police station. The building was composed of two large blocks and located right next to the Goth column, in front of the Üçüncüyeri gate of the palace that connects the fourth courtyard to Gülhane gardens. Without any visible traces or records of the building remaining today, archival research helped me to identify the name of the police station. A document from 1897, within the collection of the Topkap1 Palace Museum Archives ${ }^{1}$ mentions the names of the structures on the route from Demikapı gate to the prayer area (namazgâh), on which Abdülhamid Il would pass through during his annual visits to the Chamber of Sacred Relics. According to the document, there was a Hamidian Police Station (Hamidiye Karakolhanesi) located on this route. The Abdurrahman Şeref Bey map of 1911 (fig. 2) shows the location of the prayer area by the Üçüncüyeri gate of the palace, which helped me to identify the name and location of the police station. This 'discovery' drew my attention towards the police stations within the Topkapı Palace. In the Ottoman Archives, names of several other police stations were mentioned and an archival document from 1885 confirms that there were "ten police stations" (on bâb karakolhane) within the precincts of the palace by the late nineteenth century. ${ }^{2}$ Another undated register for repairs (tamir defteri) mentions the names of ten police stations in the Topkapı Palace. ${ }^{3}$

This paper is an attempt to understand the socio-political and military rationale behind this high concentration of police stations in the Topkapı Palace, which was "abandoned" by the Ottoman dynasty during the nineteenth century. I argue in this article that transformations in the military and bureaucratic character of the state, changing visual ideologies of the
Figure 1a-1b: Album prints showing the Hamidiye police station. Library of Congress, 3 b29243u and 3 b29247r. 
Figure 2: Abdurrahman Şeref map of the Topkapı Palace.

Tarih-i Osmani Encümen

Mecmuası 6

(1 Şubat 1326 / 1911).

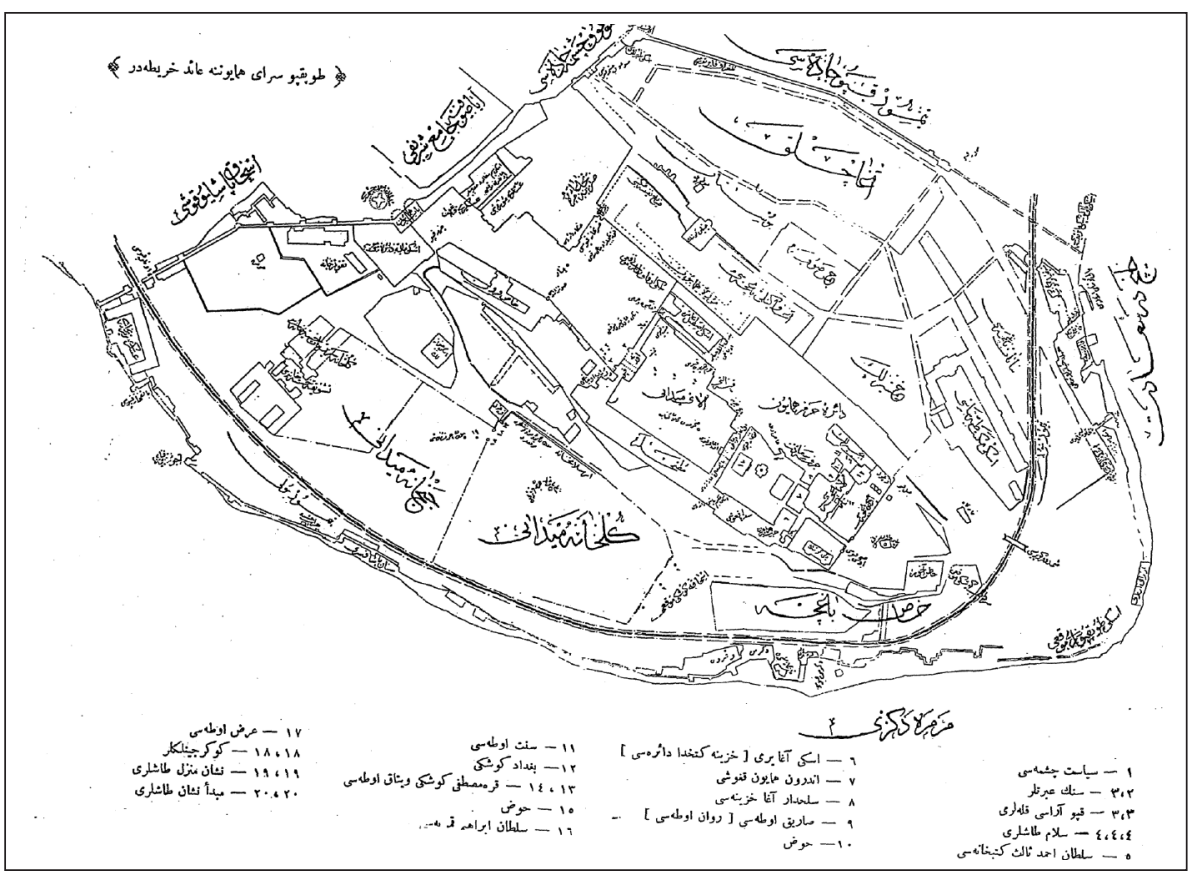

Ottomans, opening of palace grounds for touristic visits and security obsession of Abdülhamid II led to the erection of numerous police stations in the Topkapi Palace-also in the rest of Istanbul-during the late nineteenth century. I will document the police stations that were built in the Topkapı Palace and among those, I will particularly discuss the three major police stations, which were later demolished without any solid documentation. Within the scope of this article I will also offer a morphological analysis of the police stations based on their changing architectural style, suggesting that police stations emerged as a new building type in the modernizing Ottoman Empire.

This research also presents how disciplinary mechanisms were employed in the late Ottoman Empire parallel to the modernization of the state and the society. It focuses on the police forces in the Ottoman Empire and the police stations that were erected in the Topkapi Palace from the reign of Mahmud II (1808-1839) until the beginning of the Second Constitutional era (1909), with a certain emphasis on the reign of Abdülhamid Il. Modern police forces first appeared in France during the late seventeenth century and in England during the eighteenth century. Police forces were institutionalized across Europe, eventually spreading to the Ottoman Empire by the first quarter of the nineteenth century. ${ }^{4}$ Following the abolishment of the Janissary Corps in 1826, the police arose as a new institution, representing the reforms of the sovereign state, as well as its modernization and centralization..$^{5}$ During the second half of the nineteenth century, dozens of police stations were erected in Istanbul, as manifestations of the controlling gaze of the new regime over its subjects.

As the state apparatus centralized around the sultan, it became more authoritative and oppressive during the reign of Abdülhamid II; the visibility, scale, and number of the police stations also amplified accordingly. In this respect, the article suggests that the police stations that were built, modified, expanded, and demolished in the Topkapı Palace during the long nineteenth century can be studied as pertinent spatial tools for the mechanisms of discipline and surveillance in the modernizing empire. The research utilizes previously unpublished archival and visual material to document and analyze the remaining and forgotten police stations and their sociopolitical impacts within the urban context of Istanbul.

4 Thomas Whetstone, William F. Walsh et al., "Police," Encyclopædia Britannica, accessed November, 12 2019, https://www.britannica. com/topic/police.

5 Ferdan Ergut, Modern Devlet ve Polis: Osmanlidan Cumhuriyet'e Toplumsal Denetimin Diyalektiği (İstanbul: İletişim Yayınlanı, 2004). 
The emergence of police forces is a direct outcome of the military and bureaucratic reforms that transformed the traditional state apparatus and social structure in the Ottoman Empire. ${ }^{6}$ Traditionally, the Ottoman military corps was responsible for maintaining public order and security in the cities. On the other hand, the Imperial Gardeners (Bostancı Teşkilatı), who were responsible for the cultivation of the outer gardens of the palace, were also in charge of the security of the palace grounds. With the abolishment of the janissaries in 1826 by Mahmud II, the Ottoman military and public security system was completely restructured, and the modern military army was established. Based on the new military regime, the Bostancı organization was reconfigured, renamed as asakir-i hassa and became responsible for the security of the imperial palaces and the Istanbul coastline. ${ }^{7}$

Police stations (karakolhane), as a new building type started to appear in Istanbul during the reign of Mahmud II, especially after the abolishment of janissaries. As early as 1827 , police stations emerged in various parts of the city, often at the very locations of demolished janissary buildings. ${ }^{8}$ The architectural configurations of police stations became regulated with a legislation published in 1831-1832. ${ }^{9}$ According to this legislation, the new police stations were to be constructed in masonry instead of timber by the Department of Imperial Buildings (Ebniye-i Hassa Müdüriyeti). ${ }^{10}$ Another imperial decree dated 1833-1834 (h.1249) regulates the architectural features and locations of the police stations. ${ }^{11}$ According to the research of Yekta Özgüven, during the reign of Mahmud II, seven police stations were built in the Historic Peninsula, five along the Bosporus, three in Üsküdar, and two in Eyüp. ${ }^{12}$ Police stations could be recognized by their neoclassical architecture-triangular pediments and colonnaded porticoes-which reflected the military and institutional reforms of Mahmud Il and the westernization endeavors of the era.

Topkapı Palace during this period was used less as an imperial residence but more as a governmental and military center. The protected domains of the Topkapi Palace was used as a test ground for the reforms of Mahmud II, some of which were executed within the complex. I believe the earliest police stations in the Topkapı Palace were erected during this period as an outcome of the physical and institutional reconfiguration of the royal complex.13 One of the most visible and significant examples would be the one built at the Seraglio Point, outside the walls of the palace. This neoclassical building (fig. 3) could easily be recognized in the earlier photographs and engravings of Seraglio, right next to the Topkapusu (Cannon Gate) Summer Palace, which was extended and remodeled by Mahmud II. ${ }^{14}$

Although no archival records could be found regarding the construction date and original function of this edifice, I suggest that the building functioned as a sort of police station housing

6 The transformation and institutionalization of the security forces started as early as the late eighteenth century, during the reign of Selim III (1789-1808), with the establishment of the Nizam-l Cedid (New Order) corps and came to a conclusion during the reign of Mahmud II with the abolition of Janissaries in 1826. See Ali Sönmez, "Zaptiye Teşkilatının Düzenlenmesi (1840-1869)," Ankara Üniversitesi Dil ve Tarih-Coğrafya Fakültesi Tarih Bölümü Tarih Araştırmalan Dergisi 25, no. 39 (2006): 199-219.

7 İsmail Hakkı Uzunçarşılı, Osmanlı Devletinin Saray Teşkilâtı (Ankara: Türk Tarih Kurumu Basımevi, 1984), 481; Abdülkadir Özcan,

"Bostanc1," Türkiye Diyanet Vakfi İslâm Ansiklopedisi, v. 6 (Istanbul: TDV İslâm Araştırmaları Merkezi, 2001), 308-309.

8 Noémi Lévy-Aksu, Osmanl İstanbul'unda asayiş, 1879-1909 (Istanbul: İletişim, 2017), 169, 195.

9 Necla Arslan Sevin, "XIX. Yüzyıl Osmanlı Başkentinde Polis Teşkilatı ve Karakol Binaları," TarihTarih, accessed November 4, 2019,

https://www.tarihtarih.com/?Syf=26\&Syz=352760\&/XIX.-Y\%C $3 \%$ BCzy\%C4\%B1l-Osmanl\%C4\%B1-Ba\%C5\% ${ }_{9}{ }_{9} F k e n t i n d e-P o l i s-$

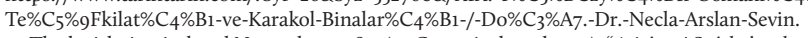

10 The legislation is dated November 1, 1831 (25 Cemaziyelevvel 1247): "Asitâne-i Saâdet'te olan ibâdullâhm sâye-i hazret-i tâc-dârîde leyi ü nehâr muhafaza ve istirahatleri için tayin ve irsal olunan Asâkir-i mansûrenin ikâmetlerine mahsus ve karakolhâneler kadîmden kalmış ve kânûn-ı mansûre üzre derûnlarında asâkirin iskân ü râhatlan emr-i muhal olduğundan bu kerre kakolhânelerin resm-i cedîde-i müstahsene üzre inşâlarına irâde-i seniyye müteallik buyurulup" cited in Osman Nuri Ergin, Mecelle-i Umûr-ı Belediyye, v. 2. (Istanbul: Istanbul Büyükşehir Belediyesi Kültür İşleri Daire Başkanlığı, 1995), 880-881.

11 BOA.HH.593.29052 (h.1249/1833-34) cited in Çiftçi, "19. Yüzyılda Osmanlı Devleti'nde Askeri Mimari ve İstanbul'da İnşa Edilen Askeri Yapılar" (PhD diss., Yıldız Teknik Üniversitesi Fen Bilimleri Enstitüsü, 2004), 242.

12 Yekta Özgüven, "Il. Mahmud Dönemi İstanbulu’nda Kentsel-Fiziksel Kavrayışın Değişimi” (PhD diss., Yıldız Teknik Üniversitesi, 2009$)$, 225.

13 During the reign of Mahmud Il, the enderun organization, where the palace pages lived in and were trained at, in the third court of the Topkapi Palace, was restructured. New buildings were erected in the royal complex and existing structures were completely remodeled. The palace became a test ground for sultan's military and institutional reforms. Nilay Özlü, "From Imperial Palace to Museum: The Topkap1 Palace During the Long Nineteenth Century" (PhD diss.,Boğaziçi University, 2018), 44.

14 Topkapusu Summer Palace was constructed by Ahmed III in the early-eighteenth century and later remodeled by Mahmud 1 (1730-1754) and Selim III. The final and most extensive remodeling was conducted during the era of Mahmud II and the Topkapusu Summer Palace was vastly extended in his time. The Seraglio fire of 1863 completely destroyed this palace. See: Gülru Necipoğlu, Architecture, Ceremonial, and Power: The Topkapt Palace in the Fifteenth and Sixteenth Centuries (New York, Cambridge: Architectural History Foundation, MIT Press, 1991), 225; Ahmet Lütfi Efendi and M. Münir Aktepe, Vaka-nüvis Ahmed Lütfi Efendi Tarihi (İstanbul: İstanbul Üniversitesi Edebiyat Fakültesi, 1984), 1009; Abdurrahman Şeref, "Topkapı Saray-1 Hümayunu," Tarih-i Osmani Encümeni Mecmuası 5 (1 Kanunievvel 1326 [1910]): 265-266; Necdet Sakaoğlu, The Imperial Palace with its History, Locations, Inscriptions and Memoirs: Topkapt Palace (İstanbul: Denizbank Publications, 2002$), 44$. 
Figure 3: Detail from the Seraglio Point in 1855 and the Seraglio Point police station in front of the Topkapusu Summer Palace. SALT Research.

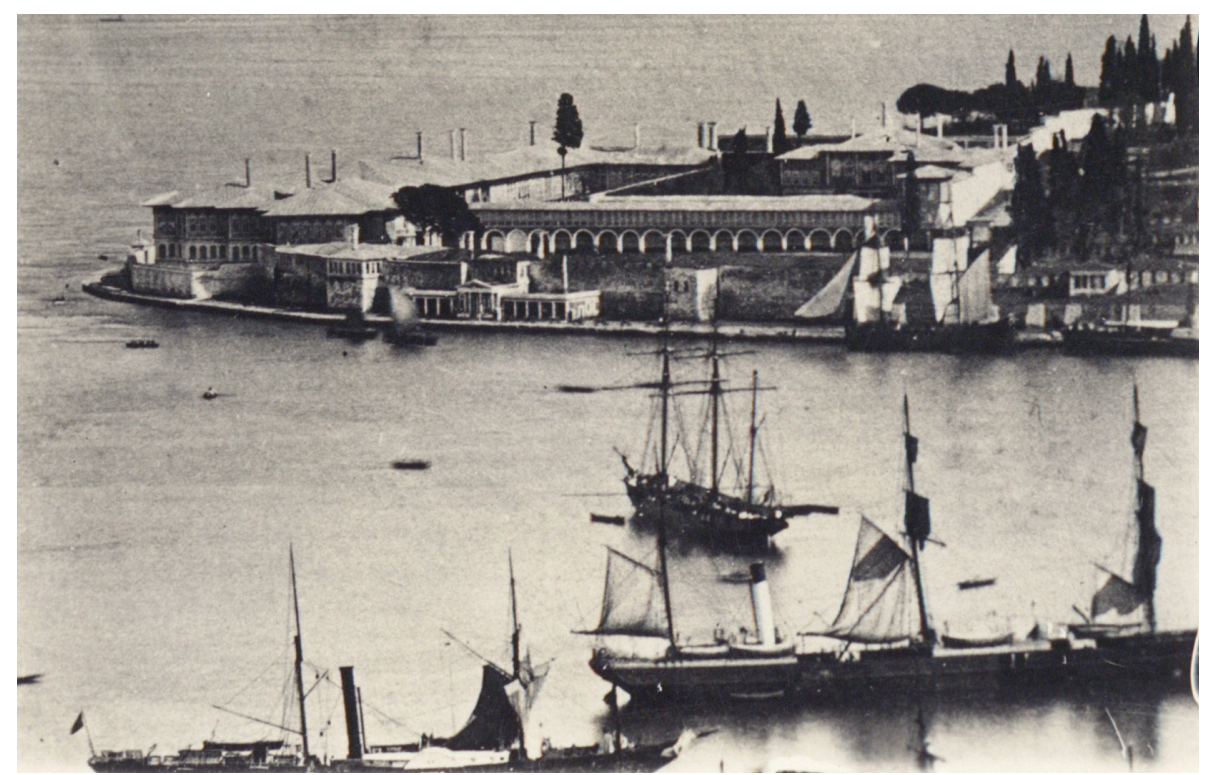

the corps responsible from the protection of the palace. It could have been built as a part of the new Topkapusu Summer Palace to protect the enlarged royal complex and also to manifest the power of the authoritarian ruler. With its neoclassical architectural elements-symmetrical configuration, colonnaded façade, projected four-column portico, and triangular pediment at the entrance-the masonry building represented the ideology of Mahmud II. One can also propose that this highly symbolic and visible edifice was built to compensate the absence of the two towers along the Topkapusu seagate of the palace, which traditionally guarded the royal complex. ${ }^{15}$ Hence, by the early nineteenth century, the protection of the palace grounds and the sultan was symbolically transferred from traditional palace corps to centralized forces, from ancient towers to a modern building, from vertical emphasis to horizontal visibility.

Another police station from the reign of Mahmud II inside the Topkapi grounds was built next to the Imperial Mints (Darphane-i Amire). As a part of Mahmud Il's fiscal reforms, the assets of the pious foundations (vaklf) were appropriated and placed under the control of the Imperial Mints and the complex was renovated and extended, with the addition of a new imperial kiosk..$^{16}$ The photographs from the late nineteenth century show the building with a portico and a triangular pediment, which is missing today (fig. 4). This small neoclassical structure was characterized by the depiction of sunrays on its pediment. Earlier photographs of the nearby Imperial Mints Pavilion show that the police station and the kiosk shared a common architectural language, as both neoclassical buildings had sunrays depicted on their pediments. ${ }^{17}$ Another comparable example from the era of Mahmud II, the Tevfikiye police station, reflects similar architectural features. ${ }^{18}$

The construction of police stations continued during the reign of Abdülmecid (1839-1861). Following the declaration of Tanzimat Decree in 1839, the government enacted modernizing reforms, which included dividing the public security and military power by creating a police force separate from the army. ${ }^{19}$ However, in the early years of the Tanzimat period, old and new institutions coexisted, and this era of transition continued until $1845 .{ }^{20}$ During that time, the Marshalcy of the Police Forces (Zaptiye Müsiriyeti) was founded and put in charge of public

15 The twin towers that were located at the tip of the Seraglio to protect the main sea gate of the palace were demolished during Mahmud Il's reconstruction of the Topkapusu Summer Palace. The image of these towers were so powerful in the public memory that the palace (previously referred as Saray-ı Cedid) was renamed as Topkapı Palace following the demolition of these towers.

16 Coskun Yilmaz, II. Mahmud: Yeniden Yapılanma Sürecinde İstanbul / Istanbul in the Process of Being Rebuilt (Istanbul: İstanbul Avrupa Kültür Başkenti, 2010); Pars Tuğlac1, The Role of Balian Family in Ottoman Architecture (Istanbul: YÇK, 1990). 17 Tuğlacı, Role of Balian Family, 40.

18 Çiftçi, "Karakol," TDV İslâm Ansiklopedisi, v. 24 (ìstanbul: TDV İslâm Araştırmaları Merkezi, 2001), 431.

19 Nadir Özbek, "Policing the Countryside: Gendarmes of the Late-Nineteenth-Century Ottoman Empire (1876-1908)," International Journal of Middle East Studies 40, no. 1 (2008): 47-67.

20 Ergut, Modern Devlet ve Polis, 84. 


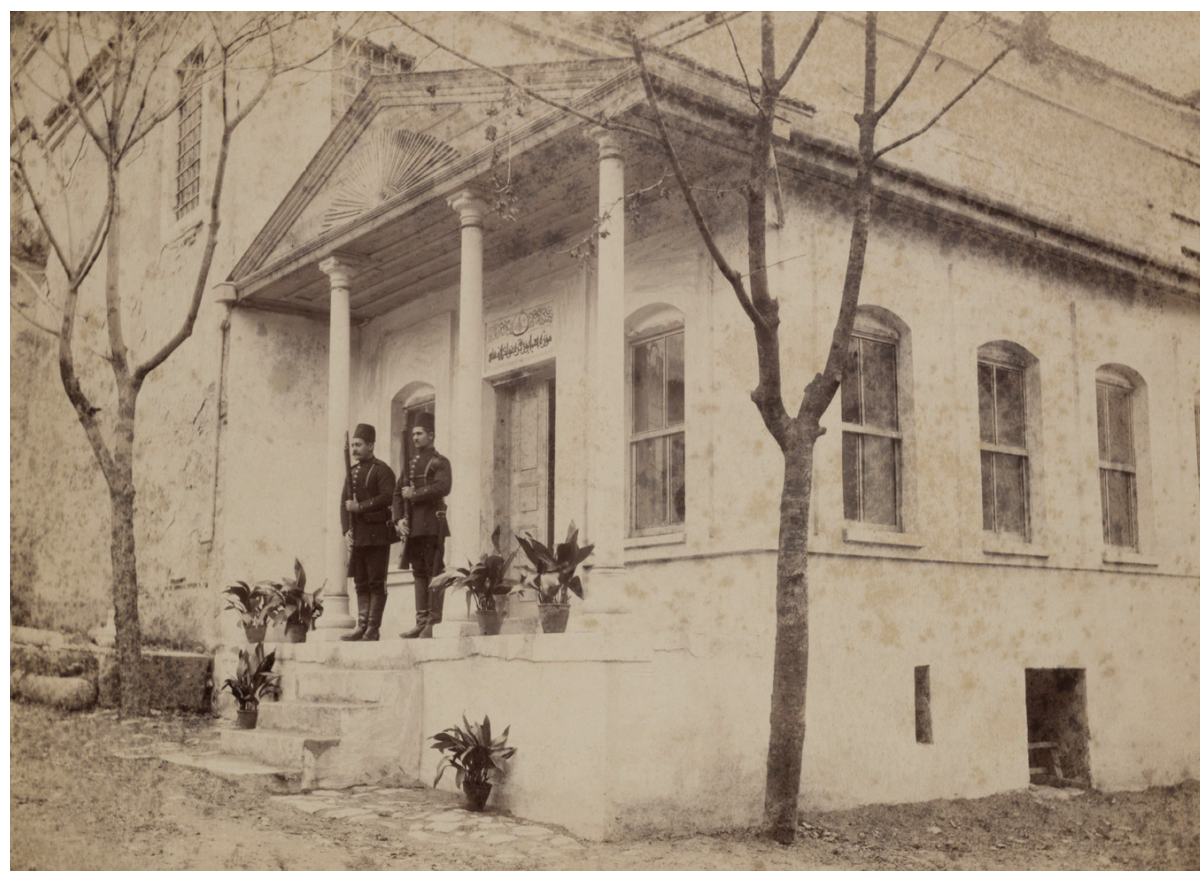

security. ${ }^{21}$ As a step towards creating a separate civilian police force inspection officers were established. The term "police" was first introduced in 1845 to define this division of the gendarmerie corps. ${ }^{22}$ Police forces had a significant role in the establishment of the new legal and social order offered by the Tanzimat reforms. According to Stefanos Yerasimos, with the reconfiguration of the urban landscape during this period, public order and uprisings were better controlled. ${ }^{23}$

Demirkapı Barracks were constructed for the new modern army during the reign of Abdülmecid in the outer gardens of the palace next to its Demirkap1 gate. ${ }^{24}$ Most probably, the Mekteb-i Tibbiye (School of Medicine) police station marked on an Ottoman military map of 1909 (fig. 5) was a part of this military complex and was referring to the building known as Demirkap1 Karargâhı within the Demirkapı Barracks. ${ }^{25}$ The police stations, as architectural symbols of the newly established Tanzimat ideology, represented the modernization of the state and the rise of the civil bureaucracy during the reigns of Abdülmecid and Abdülaziz. Especially during the time of Abdülaziz (1861-1876), numerous small to mid-scale police stations were erected almost in every neighborhood of Istanbul. Necla Arslan suggests that the number of police stations in Istanbul reached 232 as of $1863 .{ }^{26}$

However, it was not until the Hamidian era that the police forces were effectivelyinstitutionalized. ${ }^{27}$ During the reign of Abdülhamid II, in line with the centralization and modernization of the state, the concept of a distinct police institution was finally implemented. In 1879 , police was separated from gendarmerie, and, in 1881, a separate police force was officially founded with the establishment of the Ministry of the Police Forces ${ }^{28}$ With the establishment of this civilian organization, police forces were finally detached from the military forces and became responsible for public order and security, primarily in Istanbul and later in other parts of the empire. In fact, during the reign of Abdülhamid II, police forces-together with espionage networks-
Figure 4: The neoclassical police station by the Darphane Gate of the palace with its colonnaded portico and sunrays on its pediment. İstanbul Üniversitesi Nadir Eserler Kitaplı̆̆ı, Yıldız Albümü.

21 Sönmez, "Zaptiye Teşkilatının Düzenlenmesi (1840-1869)," 202.

22 Lévy-Aksu, Osmanl İstanbul'unda Asayiş, 171.

23 Stefanos Yerasimos, "Tanzimat'in Kent Reformları Üzerine," Modernleşme Sürecinde Osmanlı Kentleri, ed. Paul Dumont and François Georgeon (Istanbul: Tarih Vakf1 Yurt Yayınları, 1996) 1-18.

24 Nurçe Düzalan, “Demirkapı Kıșlası’nın Tarihsel Gelișimi” (MA thesis, İstanbul Teknik Üniversitesi, 2011).

25 BOA, Y.EE.00o64

26 Salname-i Devlet-i Aliye-i Osmaniye, 128oh /1863, 91 cited in Necla Arslan, "II. Mahmut ve Abdülmecit Dönemi Karakol Binalar1," Uluslararası Dördüncü Türk Kültürü Kongresi Bildirileri (Ankara: Atatürk Kültür Merkezi Yayınları, 1997), 69-84.

27 Süheyla Nil Mustafa, "Making of the Ottoman Policemen (1876-1918)" (PhD diss., Boğaziçi University, 2018), 18.

28 Mehmet Salkımlı and Yılmaz Örsel, Osmanlı Devleti Emniyet-i Umumiye 10 Nisan 1845: Türkiye Cumhuriyeti Polis Tarihi (Istanbul: Gökso

Ofset Matbaacilik, 1990), 5 . 
Figure 5: The map of police stations in Istanbul by the end of Abdülhamid Il's reign. BOA, Y.EE. 64/6 (6 Rabiulahir 1327 [April 27, 1909]).

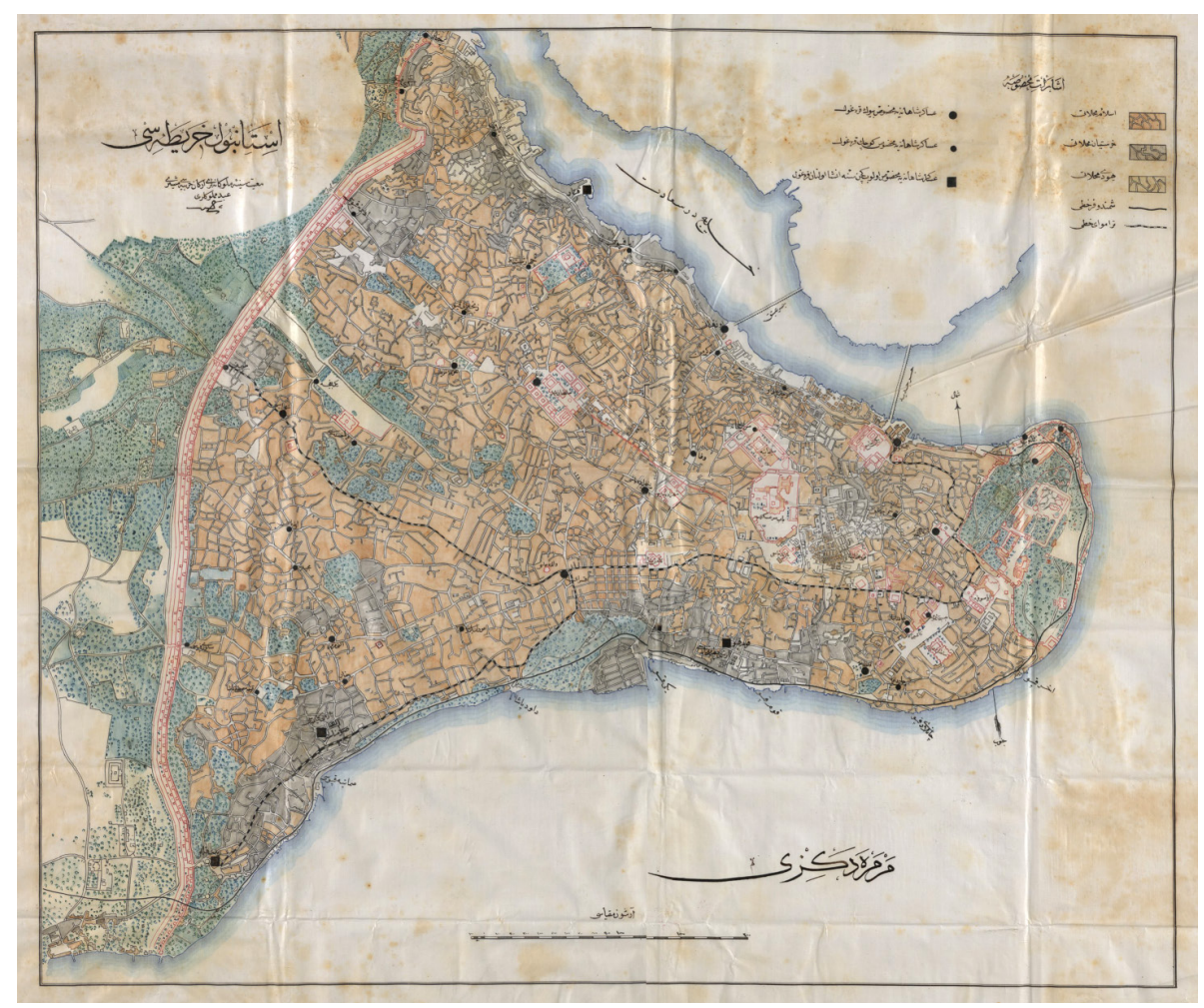

were mostly responsible for the control and surveillance of Ottoman elites and local power groups. ${ }^{29}$ The Ministry of the Police Forces operated throughout the Hamidian era, until being reorganized as the Department of Public Security in 1909. During this period, due to the centralization and rising public surveillance and control policies, police forces were modernized and institutionalized, and became one of the most significant leitmotifs of the regime.

The expenditure on police forces during the Hamidian era was almost "14\% of the state budget," much higher than other institutions. ${ }^{30}$ As of 1902 , there were 2,275 police officers and thirty-three police departments in Istanbul alone. ${ }^{31}$ In 1912 the number of policemen in Istanbul reached 2,500 in comparison to a total of 3,971 police officers within the provinces of the empire..$^{32}$ The policemen were mostly recruited from among the Muslim urban poor between the age of twenty-one and fifty and did not have formal training up until the Second Constitutional period. Their salaries were generally low and depended on their ranks, which included director, inspector, superintendent, commissar, second-class commissar, third-class commissar, sergeant, and police officer. ${ }^{33}$ Having a reputation for espionage and sleuthing especially during the reign of Abdülhamid II, the police forces were mainly responsible of surveillance, conflict resolution, and maintaining public order within Ottoman society. Additionally, the police, as an enforcement agency, was one of the symbols and guardians of the oppressive Hamidian regime. ${ }^{34}$ As the police forces represented the internal dynamics of Ottoman society and the transformation of the military and bureaucratic structure, police stations emerged as a new building type that manifested the controlling mechanisms of the state within urban precincts.

29 Ergut, Modern Devlet ve Polis, 143-44.

30 Stanford J. Shaw and Ezel Kural Shaw, History of the Ottoman Empire and Modern Turkey. Reform, Revolution, and Republic: The Rise of Modern Turkey, 1808-1975, v.ll (Cambridge: Cambridge University Press, 2005), 225.

31 Lévy-Aksu, Osmanlı İstanbul'unda Asayiş, 176.

32 Mustafa, "Making of the Ottoman Policemen (1876-1918)," 31-34.

33 Süheyla Nil Mustafa provides detailed information on the organizational culture, institutional and social configuration, educational background, demographics, income level, ethnic and religious origins of the policemen in the Ottoman Empire. See Süheyla Nil Mustafa, "Organizational Culture of the Ottoman Police," Perspectives in Communication Studies Festschrift in Honor of Prof. Dr. Ayseli Usluata, ed. Ayşe Binay Kurultay and Burcu Sabuncuoğlu (Frankfurt: Peter Lang Publishing, 2016), 147-160; "Osmanlı Polisinin Kurumsal Medyasinda Polis-Jandarma İlişkisi ve Temsili," Miras ve Değişim: Osmanlidan Cumhuriyet’e Jandarma, ed. İsmail Hakkı Demircioğlu, Ahmet Özcan, Yücel Yiğit (T.C. Polis Akademisi Bașkanlığı Ankara: Berikan Yayınları, 2018), 77-83; "Making of the Ottoman Policemen (1876-1918)." 34 Lévy-Aksu, Osmanlı İstanbul'unda Asayiş, 169-170. 
The Ottoman/Turkish word for police station, karakol, is etymologically derived from the Mongolian word that means surveillance and watching. ${ }^{35}$ Apparently, the word karakol refers to the mechanisms of discipline and control for monitoring the subjects of the sovereign, which was-and still is-carried out by the police apparatus in modern society. The police take over a number of pre-existing but diverse functions, such as the criminal search, urban surveillance, and economic and political supervision, and transpose them into a "single, strict administrative machine," which is capable of making everyone visible but keeping itself invisible. ${ }^{36}$ Abdülhamid II, who restructured the Ottoman state and bureaucracy during his thirty-three years of rule, transformed the urban landscape of Istanbul, reflecting his centralized rule and modernizing ideology. ${ }^{37}$ As explained above, during the Hamidian era, police forces were thoroughly institutionalized and regularized. Therefore, new police stations were erected in various parts of the capital and the empire. These new police stations were built following a certain architectural configuration, as solid embodiments of the regime. These small, yet highly visible and symbolically significant structures bore the imperial coat of arms and became one of the architectural epitomes of the era, together with schools, hospitals, train stations, fountains and clock towers. ${ }^{38}$

The architectural features of the police stations started being regulated as early as 1830 s and the buildings were more-or-less standardized during the Hamidian era. For instance, technical construction manuals published in 1888,1889 , and 1896 included sections defining the architectural characteristics of the police stations. According to the 1888 publication of Usul-i Keşf-i Inşaat (Manual of Construction), a police station having a capacity of thirty men should include a ward, rooms for officers and servants, lavatory and toilets. The station could also contain service spaces such as kitchen, larder, woodshed, and laundry and these should be designed according to the scientific architectural methods of the time..$^{39} 1896$ publication of Fenn-i Inşaat (Science of Construction) provides details about the architectural characteristics and defensive function of the police stations, emphasizing that the doors and windows should be crenellated to resist any possible attacks..$^{40}$

Fenn-i İşaat manuals also included architectural drawings, specifying the organizational scheme and size of spaces designated for various functions within the police stations. According to these drawings, there were two types of police stations: centrally planned and elongated. The former is smaller in size and the spaces are configured symmetrically around a central hall, which is defined by an elaborated entrance portico. The latter is larger in scale and inner spaces and rooms are organized on two sides of a central corridor. The spaces that include commander room, doctor's room, servant room, wards, masjid, meeting hall, depots, lavatories, kitchen, laundry and jail are designated for various functions and officers, based on their ranks. ${ }^{41}$

A series of photographs from the albums of Abdülhamid Il show centrally planned police stations at various locations in Istanbul. These double-story masonry structures were mostly characterized by distinctive architectural and decorative features that differ from the neoclassical style of the previous eras (fig. 6a-6d). The most distinctive architectural element is the centrally positioned watchtower, manifesting an accentuated vertical visibility. The centrally positioned flagstaff, the round window underlining its surveillance function and the coat of arms on the tower were distinctive marks of its imperial and military significance. The symmetrical plan of the structure was emphasized, with a projected central entrance gate. In most of the buildings, the window frames on the ground floor had arches and those

35 "Karakol," Nişanyan Sözlük, accessed November 12, 2019, https://www.nisanyansozluk.com/?k=karakol.

36 Michel Foucault, Discipline and Punish: The Birth of the Prison (New York: Pantheon Books, 1977), 213-214.

37 Selim Deringil, The Well Protected Domains (New York: I.B. Tauris \& Co., 1999).

38 Darin Stephanov, Ruler Visibility and Popular Belonging in the Ottoman Empire, 1808-1908 (Edinburgh: Edinburgh University Press, 2018); Mehmet Bengü Uluengin, "Secularizing Anatolia Tick by Tick: Clock Towers in the Ottoman Empre and the Turkish Republic," International Journal of Middle Eastern Studies 42, no. 1 (2010): 17-36; Coşkun Yılmaz, II. Abdülhamid: Modernleşme sürecinde İstanbul / Istanbul during the modernization process (Istanbul: İstanbul Avrupa Kültür Başkenti, 2010).

39 Usul-i Keşf-i İnşaat (1303/1888), cited in Çiftçi, “19. Yüzyılda Osmanlı Devleti'nde Askeri Mimari," 243-244.

40 Fenn-i Inşaat (1312/1896), cited in Çiftçi, "19. Yüzyılda Osmanlı Devleti’nde Askeri Mimari," 243.

41 lbid., 243. 
Figure 6a-6d: Police stations from the era of Abdülhamid Il with similar morphologies: Sariyer-Mesar Burnu, Koşuyolu, Büyükdere, Pazarbaşı and Yıldız police stations. Library of Congress, 3b29219u, 3b2923ou, 3 b2922ou, and 3b29221u.
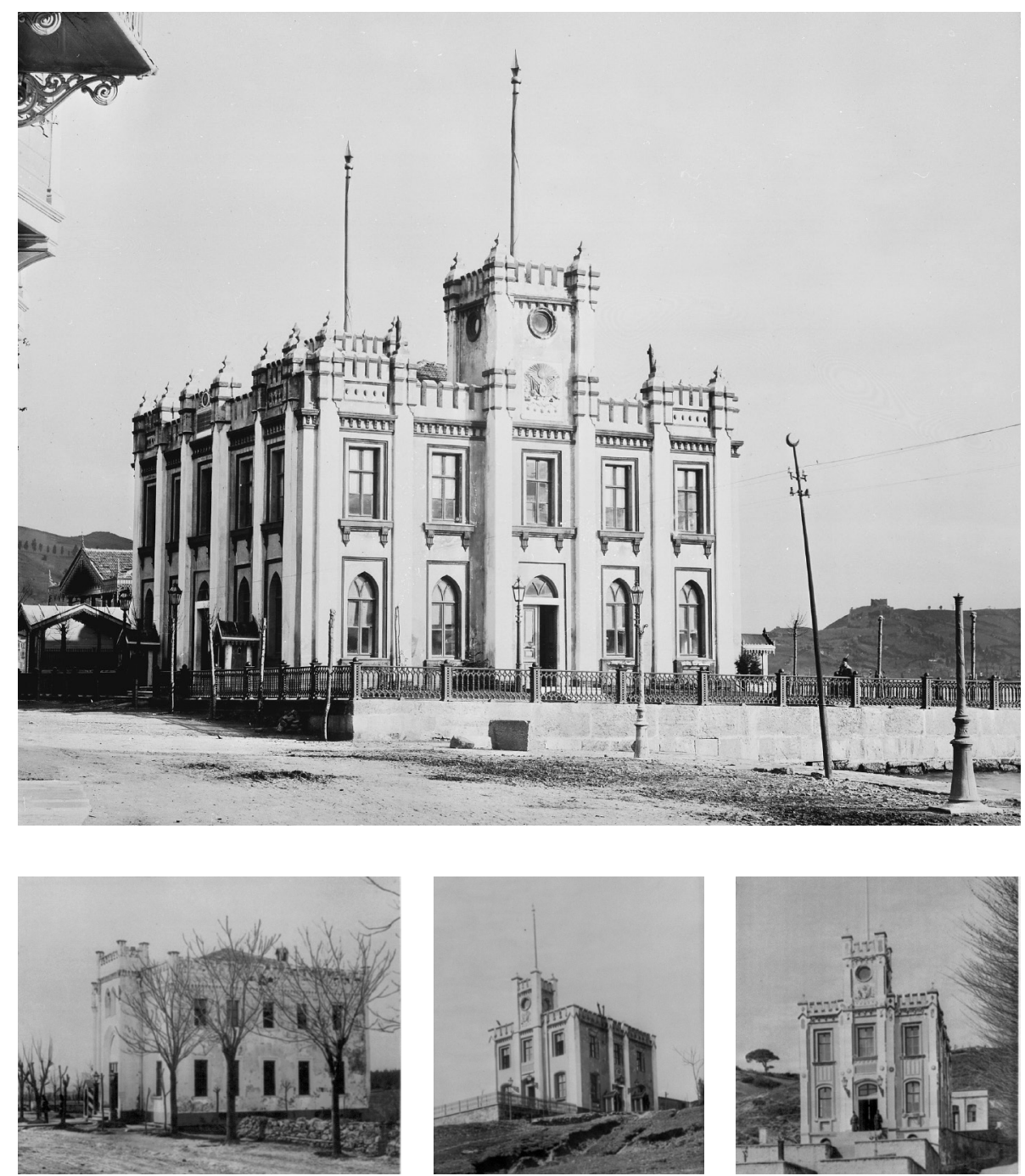

on the upper story were rectangular and the crenellated parapets of the building were derived from a defensive architectural vocabulary and communicated the militaristic function of the building. These edifices were mostly built at critical and highly visible locations, such as by piers, on busy streets, at hill-tops, and in and around the royal facilities.

A map from the final year of Abdülhamid Il's reign (1909) shows the network of major military police stations within the city (fig. 5). According to Çiftçi, after 1826, a total of seventeen military police stations (askeri karakol) were erected in Istanbul during the course of the nineteenth century..$^{42}$ Among these military police stations, six of them were placed within the precincts of the Topkapı Palace. In contrast, only one military police station was built for Dolmabahçe, two for the Yıldız, and two for the Çırağan Palaces. The high number of military police stations built within the imperial walls of the Topkap1 Palace, which was already abandoned by the royal family, is striking and deserves further investigation. 
During the reign of Abdülhamid II, the Topkapı Palace, which has lost its function as the imperial residence and the seat of the empire, still maintained its political, ideological, ceremonial and urban significance-a showcase of the Ottoman past and dynastic continuity. During this period, as the palace grounds and the royal collections became more accessible to visitors, the possession and control of Seraglio became a representation of the sovereignty of the ruler over its past and present. Abdülhamid II almost never left his Yildız Palace, which was protected by approximately 15,000 soldiers and two police stations, except for annual visits to the Chamber of Sacred Relics at the Topkap1 Palace. His visits emphasized the political significance of the older palace, which retained its imperial and religious importance throughout the Ottoman era. The royal visit of the sultan to the Holy Mantle of the Prophet was a symbol of dynastic continuity of the Ottoman rulers as 'caliphs' of Islam and protectors of all Muslims. The police stations along his route from Yildiz to Seraglio and within the Topkapı Palace were of critical importance for providing security for the anxious sultan during his annual visits to the Chamber of Sacred Relics.

An archival document dated 1902 provides details about the strict security measures taken during the sultan's visit to the Sacred Relics. Apart from two armed soldiers accompanied by a palace official at each door of the Chamber of Sacred Relics, twenty-two armed soldiers were stationed at various gates of the palace, and another armed group would also patrol and control these guards. ${ }^{43}$ Thus, police stations erected at strategic points of the palace not only marked the symbolic existence of the ruler and manifested the power of his authoritarian regime, but also aimed at protecting the sultan from an assassination attempt or a coup d'état. ${ }^{44}$ A series of documents from Topkapi Palace Museum Archives mention the construction and renovation of these police stations between 1882 and $1890^{45}$ and based on these documents one can argue that the total number of soldiers appointed in the palace grounds reached at least a couple of hundred. ${ }^{46}$

It should also be noted that the Topkapı Palace opened for visits by the nineteenth century and during the reign of Abdülhamid II the palatial tours for foreign tourists were standardized. By the end of the century, there were approximately sixty-five to seventy groups visiting the Imperial Treasury each year. ${ }^{47}$ Considering that the Imperial Museum, which housed invaluable collection of antiquities, was also within the walls of the palace, the protection of palace grounds and royal collections became a priority for the Ottoman state.

It is a fact that, during the reign of Abdülhamid II, the palace grounds were rigorously guarded with ten police station $s^{48}$ that were placed at strategic locations within the Topkap1 Palace. These police stations were positioned by the internal and external gates and close to significant buildings within the palace as their names suggest: Baghdad, Demirkap1, Imperial Treasury, Hamidiye, and Gülhane police stations. ${ }^{49}$ Compiling information from archival documents, 1909 map of military police stations, Abdurrahman Şeref Bey map of 1911, and Cornelius Gurlitt map of 1912, I was able to spot the locations of those police stations, of which only five remain by 2019 (fig. 7).

43 BOA, Y.PRK.SGE. 9/89 (13 Ramazan 1320 [December 14, 1902]). "Hırka-i Saadet ziyareti resm-i alisi esnasinda Topkapı Sarayı Hümayunları daire-i hazırasının her iki kapısında Kapıcı Bekir ve Mustafa Ağalarla refakatlerinde iki nefer tüfengi kullar bulundurulup emr ve muhafazaya fevkalade dikkat edeceklerine dair kendilerine tebligat-ı katiyye icra kılınmış ve diğer tüfenkyan kullarnndan dahi Üçüncü Kapıda dört ve Akağalar Kapısında dört ve Orta Kapıda dört ve Bab-ı Hümayunda iki ve Saffet Çeşmesi Kapısında iki ve Demirkapı'da iki ve Yeni Köşkün ittisalindeki kapıda iki ve Otluk Kapısında iki neferi ki ceman yirmi iki nefer tüfenkyan kullan ikame olunacak ve harem ziyareti esnasında dahi dısarıda bir tüfengi kulu gezdirileceği bu kavilden başka umum kapı ve nöbet mahallerinde ikame edilmiş olan tüfengi nöbetçilerini teftiş etmek üzere ayrıca bir tüfengi devriye kolu gezdirilecektir."

44 François Georgeon, Sultan Abdülhamid (Istanbul: Homer Kitabevi, 20o6); Mustafa Müftüoğlu, Abdülhamid Ulu Hakan mı? Kızıl Sultan ml? (Istanbul: Başak Yayınları, 2007).

45 TS.MA.E. 635/70 (10 Nisan 1306 [22.4.1890])

46 After the earthquake of 1894 , four of the police stations in the palace were severely damaged and the guardian of the Topkapi Palace requested forty tents for the soldiers who had inhabited these stations, hence the estimated number of soldiers in total. See BOA, Y.PRK. SGE 6/30 (6 Muharrem 1312 [July 10, 1894]) cited in Sema Küçükalioğlu Özkılıç, 1894 Depremi ve Istanbul (Istanbul: Iş̧ Bankası Kültür Yayınlar1, 2015), 102

47 Özlü, "From Imperial Palace to Museum," 315

48 BOA, TS.MA. 624/57 (17 Safer 1303 [November 25, 1885]).

49 BOA, Y.PRK.ASK. 258/16 (2 Haziran 1324 [June 15, 1908]).

"Bağdat karakolhanesi (kolağası yüzbașı) / Demirkapı karakolhanesi (yüzbasıl) / Hazine-i Hümayun karakolhanesi (2 mulazım-ı evvel)

Hamidiye karakolhanesi (1 mulazım-ı evvel) / Gülhane hapishanesi karakolu (2 mulazım-ı sani) / Demirkapı karakolhanesi (mülazim-ı sani)

Topkapı Sarayı karakolhanelerinden bu gece nöbetçi kalacak ümera ve zabitanın esami ve mevkii memuriyetleri..." 
Figure 7: The police stations during the reign of Abdülhamid II. Blue shows currently extant police stations; Red shows non-existing police stations. Nilay Özlü, based on the drawing of Sedad Hakk1 Eldem and Feridun Akozan, Topkapı Sarayı (Istanbul: Kültür ve Turizm Bakanlığı Eski Eserler ve Müzeler Genel Müdürlüğü, 1982), pl. 5 .

Figure 8: Cebehane police station in the Gülhane gardens. İstanbul Üniversitesi Nadir Eserler Kitaplığı, Yıldız Albümü.
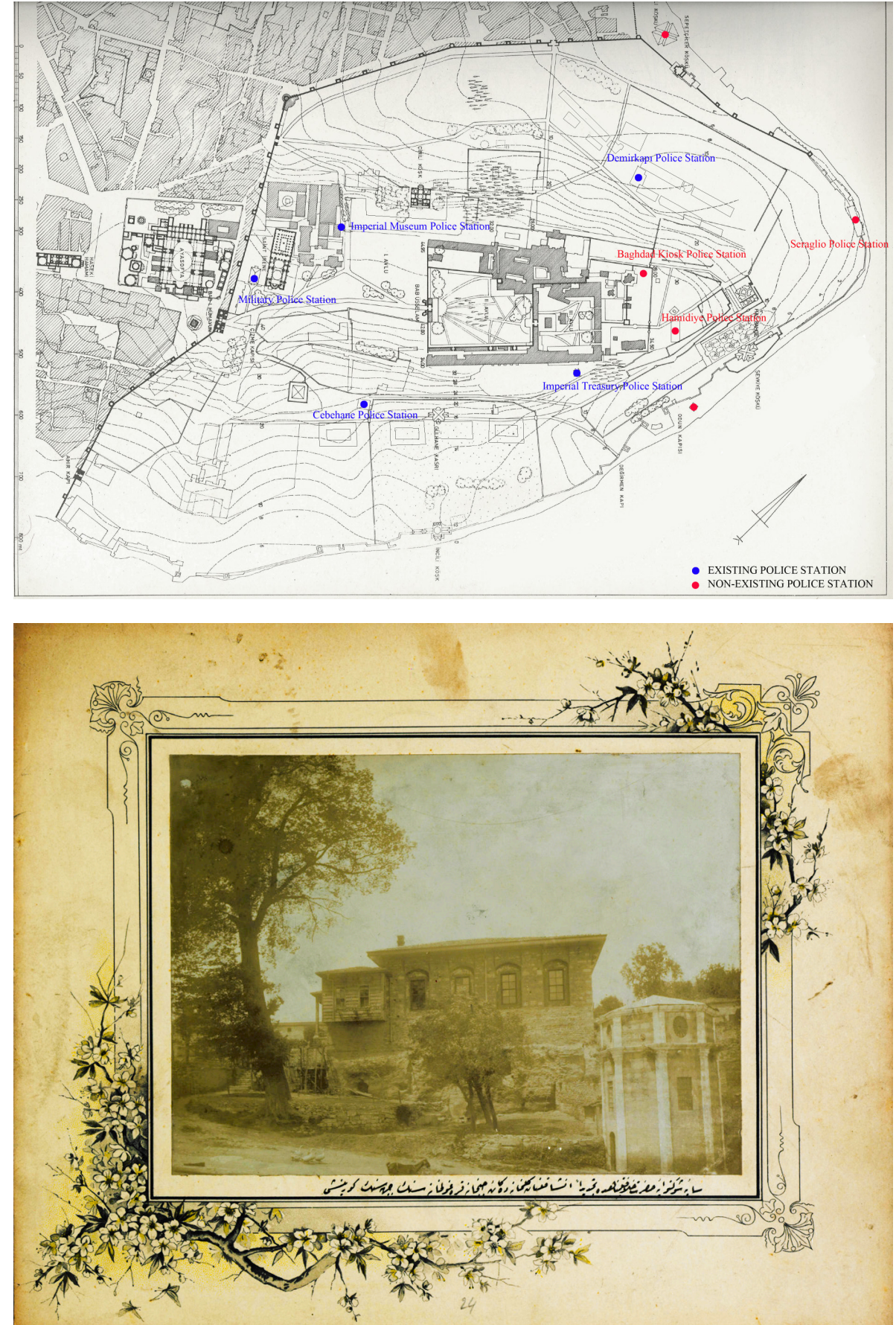

It can be argued that the police stations were among the most significant additions to the inner sections of the Topkapı Palace during the reign of Abdülhamid II, in terms of their number, architectural features, and visibility. Most of these police stations were photographed and their inaugurations were announced in the newspapers as a propaganda opportunityas exemplified by the Cebehane police station, which was located in the Gülhane gardens next to the ammunition depots (fig. 8)..$^{\circ}$ Another station in the first court of the palace is

50 For instance, a short announcement published in Ikdam in 1901 informed its readers about the opening ceremony of the Cebehane police station in the Topkap1 Palace and the attendance of several high-ranking officials. An archival document provides information about the construction date of this police station as well. TS.MA.E. 598/22 (9 Safer 1319 [May 28, 1901]). 

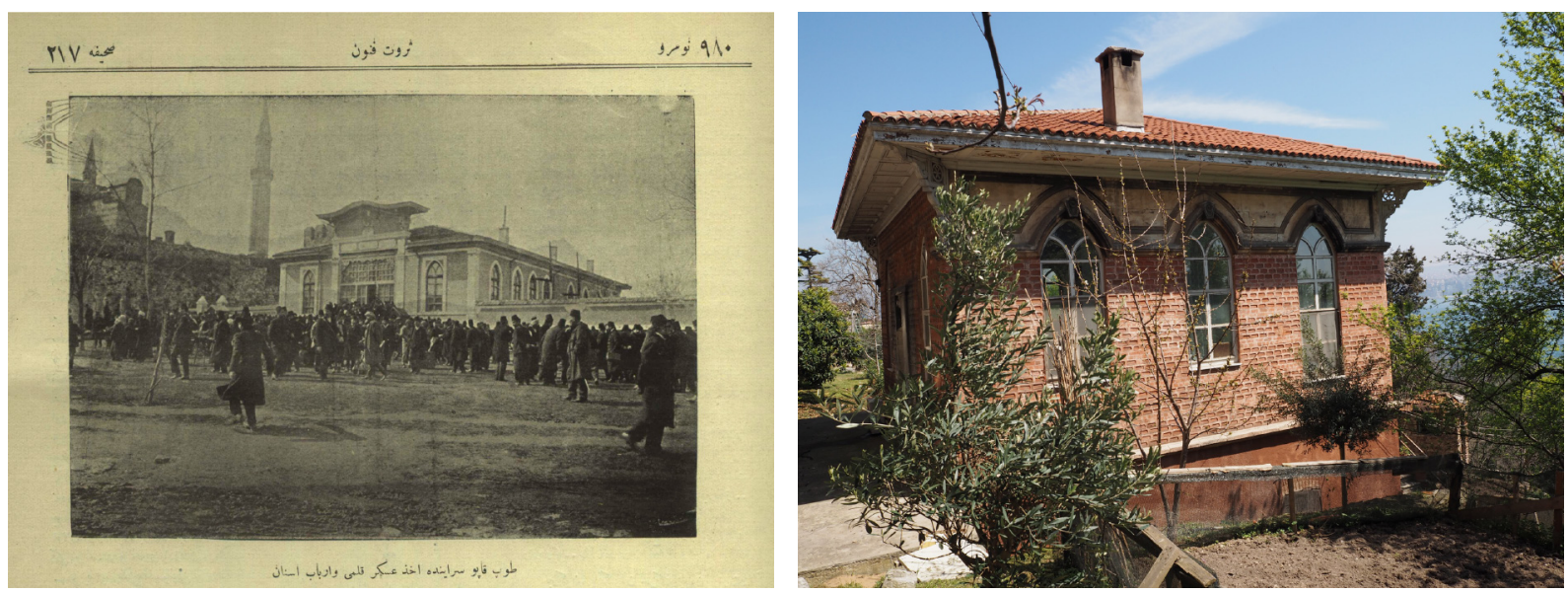

distinguished by its remarkable size and significant location-next to the Imperial Gate and the former Church of Hagia Irene. As shown in the illustrated periodicals Resimli Kitab ${ }^{51}$ and also in Servet-i Fünun ${ }^{52}$ the police station was used for new recruits for the military service (fig. 9) and marked as askeri karakol (military police station) in the Abdurrahman Şeref map. This could be the Soğukçeşme police station that was mentioned in Ottoman archival documents. ${ }^{53}$ Another police station, located on the eastern hills of the palace right below the Imperial Treasury, is still extant today. It must have been constructed to guard the precious treasury collection, which was frequently visited by foreign travelers in the late nineteenth century. The inscription on the building is dated h.1318 (1900-1901) and mentions the name of Abdülhamid Il as its patron. ${ }^{54}$ Some archival documents mention this police station, which carried the stylistic architectural features of the era, ${ }^{55}$ as the Imperial Treasury police station (fig. 10)..$^{6}$

Figure 9: The Military police station used as the recruitment office the first court of the Topkapı Palace. Servet-i Fünun 38, no. 980 (4 Mart 1326 [March 17, 1910]).

The police forces within the Topkapı Palace not only symbolized the authoritative gaze of the state over its subjects but also enforced the security of the royal complex, which was becoming a point of attraction for foreign visitors. These police stations emphasized the royal and the ceremonial significance of the Topkapı Palace and the cautious care for the precious royal and archaeological collections kept within the palace. For instance, the previously built police station by the Imperial Mints was renamed as the Imperial Museum police station. On a photograph from the late nineteenth century, monogram of Abdülhamid II and the title Müze-i Hümayun karakolhanesi (Imperial Museum police station) can be seen on the inscription above the entrance door (fig. 11). ${ }^{57}$ Therefore, it could be argued that this police station, which was erected during the reign of Mahmud II, probably for the protection of the Imperial Mints, was later restored and renamed as the Imperial Museum police station after the establishment of the archeological museum nearby. ${ }^{58}$ These police stations underlined the increasing value attributed to the archaeological and royal collections that were held and displayed in the Topkapı Palace. Parallel with the opening of Topkapı Palace to visitors and establishment of museums within, its protection became a concern for the Ottomans as stated by the director of the Imperial Museum Halil Edhem Bey. He wrote that museums in civilized nations, such as the Louvre Museum, were protected with police stations and military corps and demanded several precautions for the protection of the palace grounds, including: "Posting two guards at ancient palace gates; closing the palace gates at two o'clock;

Figure 10: Police station below the Imperial Treasury. Nilay Özlü, 2016.

55 The architectural style of the police station, especially its pointed windows and window frames, is in line with other police stations of the era.

56 BOA, Y.PRK.ASK. 258/16 (2 Haziran 1324 [June 15, 1908]).

57 The lettering of the inscription matches the stylized kufi script of the Imperial Museum, which was written by famous calligrapher Ebüzziya Tevfik Bey. The use of kufi script as an architectural element on public buildings during the Hamidian era was not unusual. See Irvin Cemil Schick, "The Revival of Kufi Script during the Reign of Sultan Abdülhamid 1l," in Calligraphy and Architecture in the Muslim World, ed. Mohammad Gharipour and İrvin Cemil Schick (Edingburgh: University of Edinburgh Press, 2013), 19-38.

58 Wendy M. K. Shaw, Possessors and Possessed : Museums, Archaeology, and the Visualization of History in the Late Ottoman Empire (Berkeley: University of California Press, 2003); Pelin Gürol Öngören, "Displaying Cultural Heritage, Defining Collective ldentity: Museums from the Late Ottoman Empire to the Early Turkish Republic" (PhD diss., Ortadoğu Teknik Üniversitesi, 2012). 
Figure 11: Imperial Museum police station. The detail of sunrays at its pediment and the kufi inscription at the door. Istanbul University Rare Works Library, Yıldız Albümü.

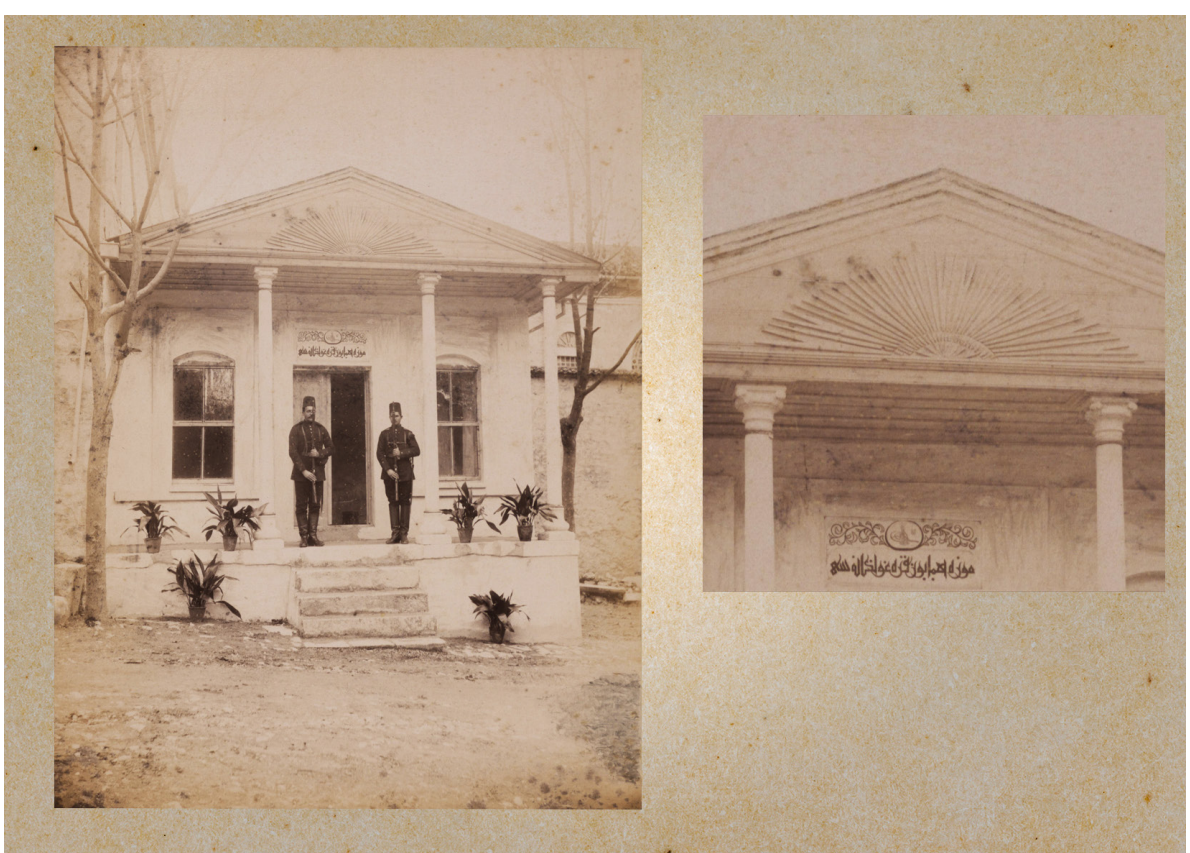

posting soldiers or gendarmeries at the Imperial Museum police station; having guards night and day at the courtyards of the Imperial Museum (......"59

\section{The 'Lost' Police Stations of the Seraglio}

Referring back to the case of the 'lost' police station that was recounted at the beginning of this article, the second part of the paper will focus on the police stations, which were erased from the landscape of the palace. Therefore, I will now analyze three police stations, which were built or reconstructed during the reign of Abdülhamid II and were demolished later without solid documentation. The Seraglio, the Baghdad Pavilion and the Hamidiye police stations were once located at the most visible and remarkable spots within the palace grounds, defining the silhouette of Seraglio (fig. 12). Even though traces of these buildings were erased both from the cityscape (fig. 13) and the public memory during the Young Turk and republican eras, I believe it is important to unveil information and compile documents regarding these ideologically and architecturally significant elements. Therefore, the rest of the article aims to shed light on these 'lost' police stations, documenting their architectural morphologies and to scrutinize the ideological dynamics behind their construction and demolition.

\section{The Seraglio Point Police Station}

Investigating the nineteenth-century panoramas of Seraglio, a careful eye cannot miss the masonry structure that stretched along the Golden Horn. It is not an exaggeration to suggest that, this symmetrical single-story building with an elaborated façade, reflecting the BeauxArts architectural principles of the era, once was one of the most notable structures of the Seraglio, dominating the vacant area at tip of the peninsula that was cleared following the Seraglio fire of 1863 .

59 BOA, MF.MKT. 1149/67 (7 Rabiulevvel 1328 [March 19, 1910]). "Zaten memalik-i mütemeddine müzelerinin kaffesinde emr-i inzibata fevkalade itina edilmekde olduğu ve hatta Luvr müzesi havlularında karakollar bulundurulduğu gibi bazı müzelerin dahiline bile asker ikame edilmekte olmastyla bu cihet kemal-i ehemmiyetle nazar-ı dikkate alınmaya şayan olduğundan mevad-ı atiyenin bil-itina dikkat ve icrast hususunun iktiza eyliyenlere emr ü tebliğini hassaten istirham eylerim Evvela: kemafis-sabık saray suru kapılarına la-akal ikişer kapıcının ikamesi; Saniyen: saat ikide kapıların kapanmasi; Salisen: Müze-i Hümayun karakoluna mikdar-ı kafi asker veya jandarma ikamesi; Rabien: Müze-i Hümayun havlularında gece ve gündüz nöbetçi beklettirilmesi; Hamisen: memerr-i ecanib dahi olan saray dahili yollarının seri'en inşa ve tamiri; Sadisen: pek az bedel-i icar mükabilinde kiraya verilmekte olan sur dahili . . . bostanların da ba'dema icara verilmeyerek bahçe haline kalb ve ifrağları icab ettiği maruzdur." 


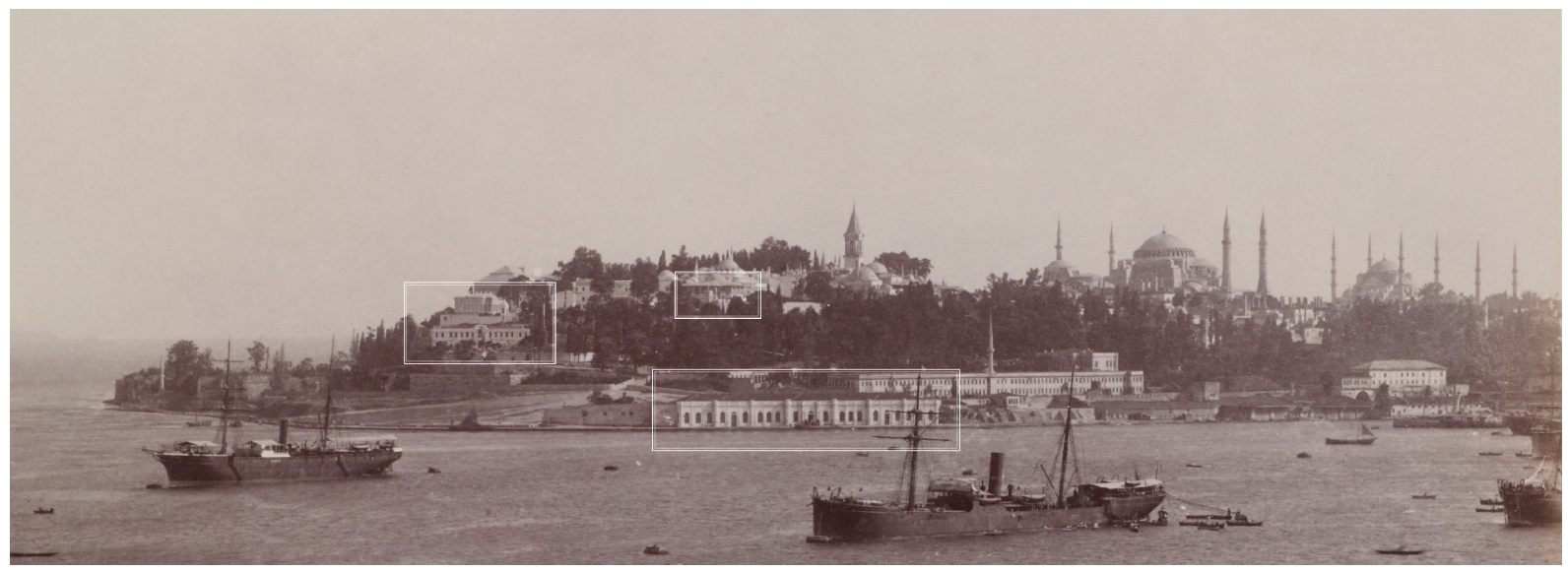

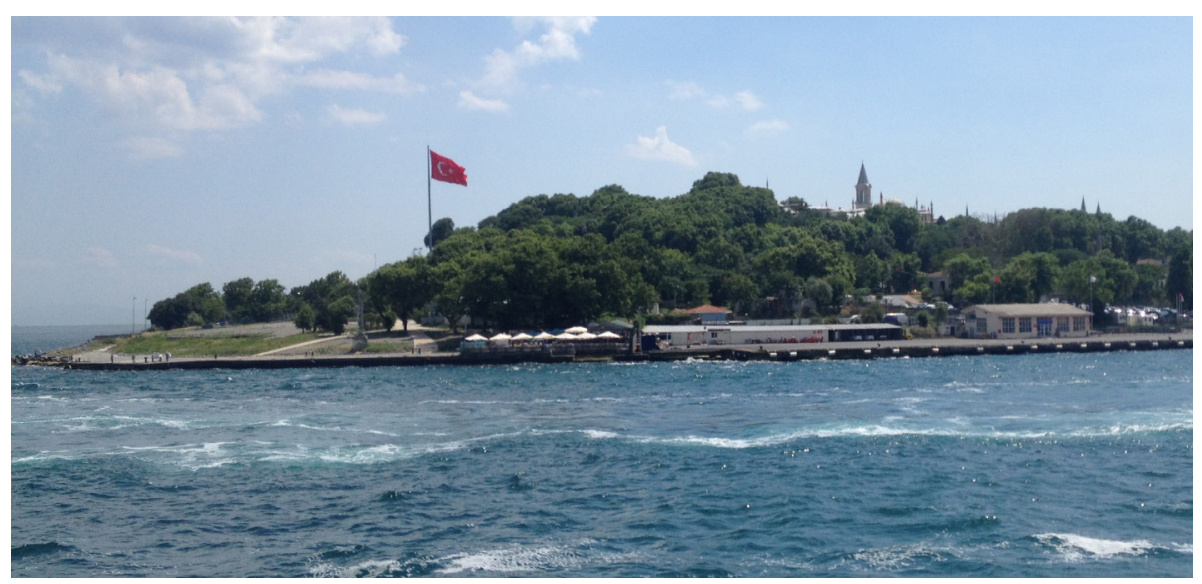

As mentioned earlier, on the spot of the same building there existed one of the earliest police stations of the Topkapi Palace, which is believed to be erected during the reign of Mahmud II. The architectural morphology of the Seraglio Point police station was transformed over the nineteenth century. Following the Seraglio fire of 1863, which destroyed the entire summer palace, the police station must have been damaged and restored by Abdülaziz; and it was renamed as the Aziziye police station. ${ }^{60}$ The architectural style of the building remained intact during this period. The original neoclassical façade of the building was completely renewed during the reign of Abdülhamid II probably following the earthquake of 1894 and replaced by a larger structure, reflecting the architectural style of the Hamidian era (fig. 12). After its reconstruction and enlargement, this building, located at the most visible point of the Seraglio and was positioned as a distinctive symbol of the Hamidian regime and controlling mechanisms of the state. The architectural style of the era could be defined as a combination of historicist and orientalist forms with neoclassical and Empire details that engaged in the Beaux-Arts principles of elaborate façade design, symmetry, and functional planning. The previous portico and pediment were eliminated, and the façade of the police station was adorned with repeating pilasters placed between arched windows. The extensions divided the façade into seven units with a projected middle unit, emphasizing the centrality and symmetry of the building. The location of this building is marked in the Abdurrahman Şeref map as one of the police stations. This prominent structure was demolished during the republican era, after the construction of the coastal road in $1956 .^{61}$
Figure 12: The Seraglio panorama and the detail showing three 'lost' police stations. Sebah \& Joaillier, Getty Archive.

Figure 13: The Seraglio Point. Nilay Özlü, 2017. 
Another police station that is not extant today was also located in the outer gardens of the Topkapı Palace, built by Sultan Abdülhamid II, and named after him. The Hamidiye police station was among the most significant and largest of the police stations built within the royal complex. It was constructed in 1890 in front of the Üçüncüyeri Gate of the palace. ${ }^{62}$ Apart from the two aforementioned prints from the Abdülhamid Il albums, there are several other photographs of this prominent police station, showing its northern, southern and western façades in the Yıldız Albums at Istanbul University Rare Works Collection. These photographs give us detailed information about this structure and its architectural configuration (fig. 14).

Hamidiye police station was composed of two separate buildings and connected with an elaborated arch adorned with the coat of arms. This coat of arms was accepted as a leitmotif of the Hamidian era and placed on almost all official and military structures of the period. ${ }^{63}$ As understood from the pictures, the police station was on the slope overlooking the Golden Horn, next to the Goth Column. It was built on an old cistern used as a basement and composed of one story on the south side and two stories on the northern side. A staircase running between the two rectangular units connects the two levels. The building was large enough to be easily noticed from the sea and from the Pera district across the Golden Horn. The building can be seen in the photographs and postcards of the era as well.

The Hamidiye police station was demolished during the construction of the Gülhane Park after the declaration of the Second Constitution in 1908. As stated in an archival document dated 1912, all buildings located in the outer gardens of the Topkapı Palace, from the Soğukçeşme Gate to the ammunition depots, were to be demolished for the reorganization of the area as a public park. ${ }^{64}$ Another document stated the need for the demolition of military structures within the area. ${ }^{65}$ The mayor of Istanbul at the time, Dr. Cemil Topuzlu, also mentioned in his memoir that he was able to demolish the large police stations and wooden barracks in the area with the help of Cemal Pasha, who was one of the most powerful ministers of the Committee

Figure 14: Northern façade of the Hamidiye police station. Istanbul University Rare Works Library, Yıldız Albümü.

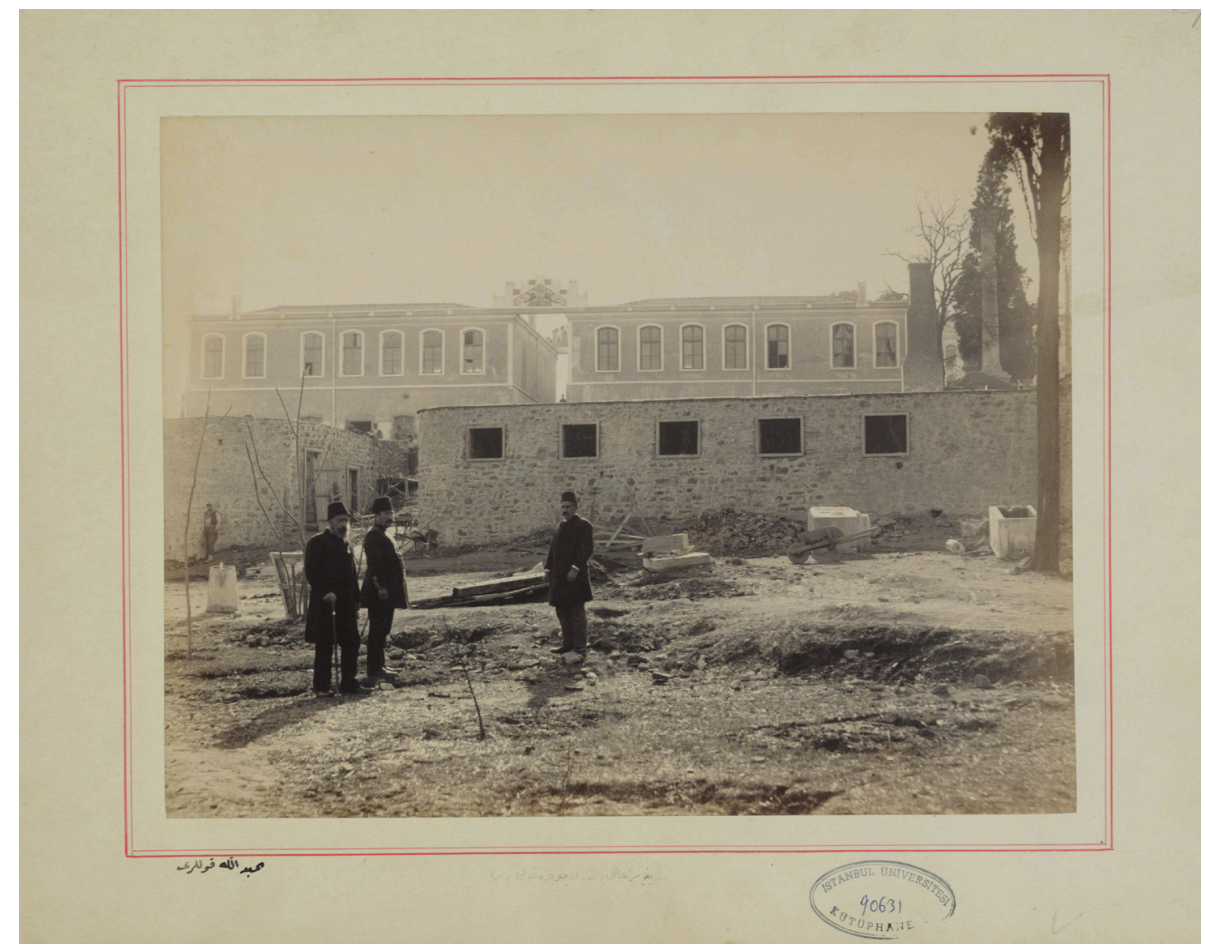

62 TS.MA. 635.70 (10 Nisan 1306 [April 22, 189o]); TS.MA. 604/35 (16 Şaban 1314 [January 20, 1897]).

63 Edhem Eldem, Iftihar ve Imtiyaz: Osmanlı Nișan ve Madalyaları Tarihi (lstanbul: Osmanlı Bankası Arșiv ve Araștırma Merkezi, 2004). 64 BOA, DH.iD. 153/10/54 (9 Tessrinievvel 1328 [October 22, 1912]).

65 BOA, DH.iD. 153/10/46 (9 Teşrinievvel 1328 [October 22, 1912]). 
of Union and Progress (CUP) government. ${ }^{66}$ An archival document from 1913 notes that the police station and the cistern underneath were demolished during the construction of the second phase of the Gülhane Park by the order of Cemal Pasha and against all the objections of the Ministry of War. ${ }^{67}$ While it is possible to spot the police station in the pictures from the Hamidian era, the building is absent in a photograph dated to 1914 (fig. 15). Today, not a single trace of this police station, which once dominated the Seraglio, can be found within the palace grounds (fig. 16). Thus, a noteworthy symbol of the Hamidian era was erased from the Istanbul's urban topography as well as its public memory.

\section{The Baghdad Pavilion Police Station}

One of the most fascinating and the least known police stations in the Topkapı Palace is the Baghdad Pavilion police station, which was also built during the reign of Abdülhamid II. In fact, this is the only police station that was built in the inner courts (Enderun) of the palace, the most secluded section of the palace dedicated to the imperial family. A photographic print from the Abdülhamid Il albums shows this remarkable police station with a caption "Corps de garde du Kiosque de Baghdad au Palais de Top Kapousu / Topkapı Saray-1 Hümayununda Bağdad Kasr-1 Hümayunu pişgahında karakolhane-i hümayun," which clearly indicates that the building was located at the Topkapı Palace "next to the Baghdad Pavilion" (fig. 17). However, it was not until I 'accidentally' came across the plan and an elevation drawings (fig. 18) of this police station in the Ottoman Archives that I could identify the exact location of the building. According to these architectural drawings, it was located on the northern edge of the Garden with Lions (Arslanlı Bahçe), in the fourth court of the palace, next to the vaulted basement of the Baghdad Pavilion. The contours of the structure is also shown in the Gurlitt map of 1912 and a "karakolhane" is indicated at the same spot on Abdurrahman Şeref Bey's map of 1911.
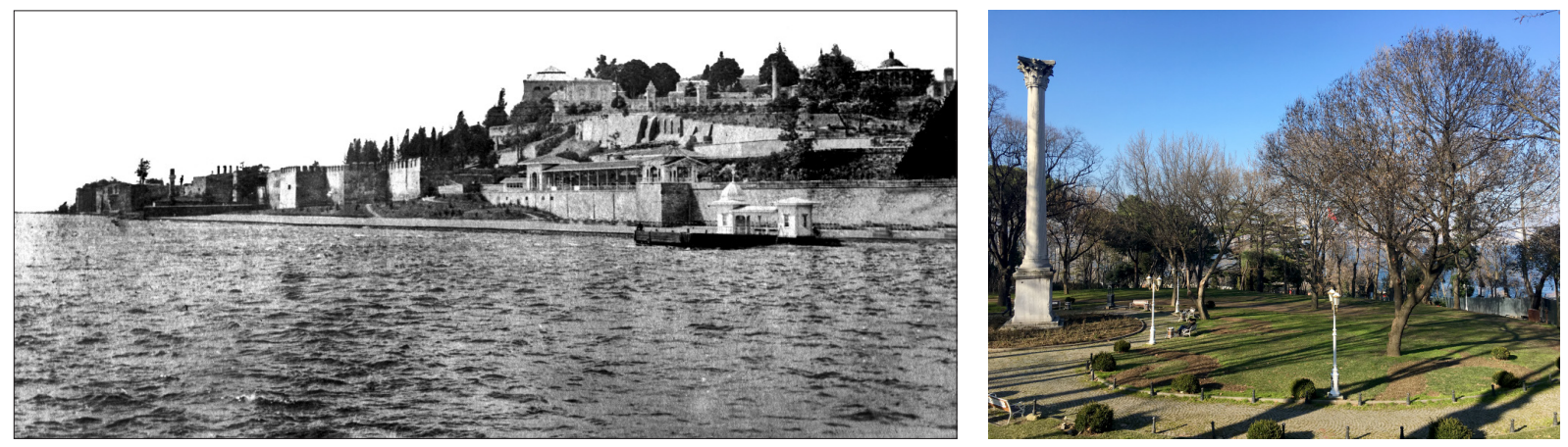

A document dated 1886 confirms the existence of a police station next to the Baghdad Pavilion, ${ }^{68}$ which was later demolished and reconstructed in June $1889 .{ }^{69}$ The inscription stones of the police station, which are being preserved in the Topkapı Palace Museum today, confirm the construction date of the building as 1889 (h.1307).$^{70}$ A renovation register dated 1889 mentions the existence of the police station below the Baghdad Kiosk. ${ }^{71}$ Construction plans and elevations found in the Ottoman Archives prove that the police station was expanded, and a refectory, a small powder magazine, and a guardroom were added to the building in $1905 .^{72}$ The police station reflected the imperial presence of Abdülhamid II at one of the most prestigious locations of the Topkapi Palace. Its elevated watchtower, which could be distinguished even from Pera and Üsküdar, made it particularly visible.

Figure 15: The view of Seraglio Point seen fro the Marmara Sea as of 1914. Courtesy of Cengiz Kahraman.

Figure 16: The site of the Hamidiye police station. Nilay Özlü, 2017.

66 Cemil Topuzlu, Hüsrev Hâtemî, and Aykut Kazancıgil, Istibdat, Meşrutiyet, Cumhuriyet Devirlerinde 80 Yıllık Hatıralarım (Istanbul: Işsaret Yayinlar1, 2010), 150-151.

67 BOA, DH.ID. 153/10/67 (9 Kanunievvel 1329 [December 22, 1913]). "Mahal-i mezkura karip iki bab karakolhanenin hedm ve ref'i için Cemal Beyefendinin vuku bulan beyanatınin..."

68 TS.MA.E. 607/5 (10 Safer 1304 [November 8, 1886])

69 TS.MA.E. 599/89 (4 Şevval 1306 [June 3, 1889]). "Topkapı Saray-ı Hümayunu nöbet mevkilerinde müteheddim asakir-i şahane efradının ikameti için Bağdad Kasr-ı Hümayunu civarinda bir bab karakolhane inșast..."

70 Çiftçi, "19. Yüzyılda Osmanlı Devleti’nde Askeri Mimari," 274.

71 BOA, TS.MA.d. 474 (27 Şaban 1306 [28.4.1889])

72 BOA, PLK.p. 481 (15 Eylül 1321 [September 23, 1905]). 


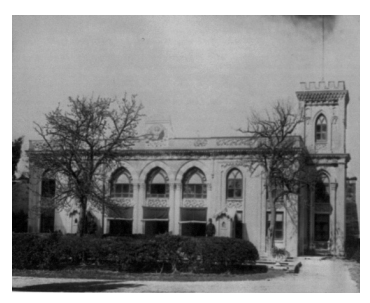

Figure 17: The Baghdad Pavilion police station. Abdülhamid II Albums, Library of Congress, 3b29236u.

Figure 18: The plan and elevation of the Baghdad Pavilion police station. BOA, PLK.p. 481

(15 Eylül 1321 [September 28, 1905]).

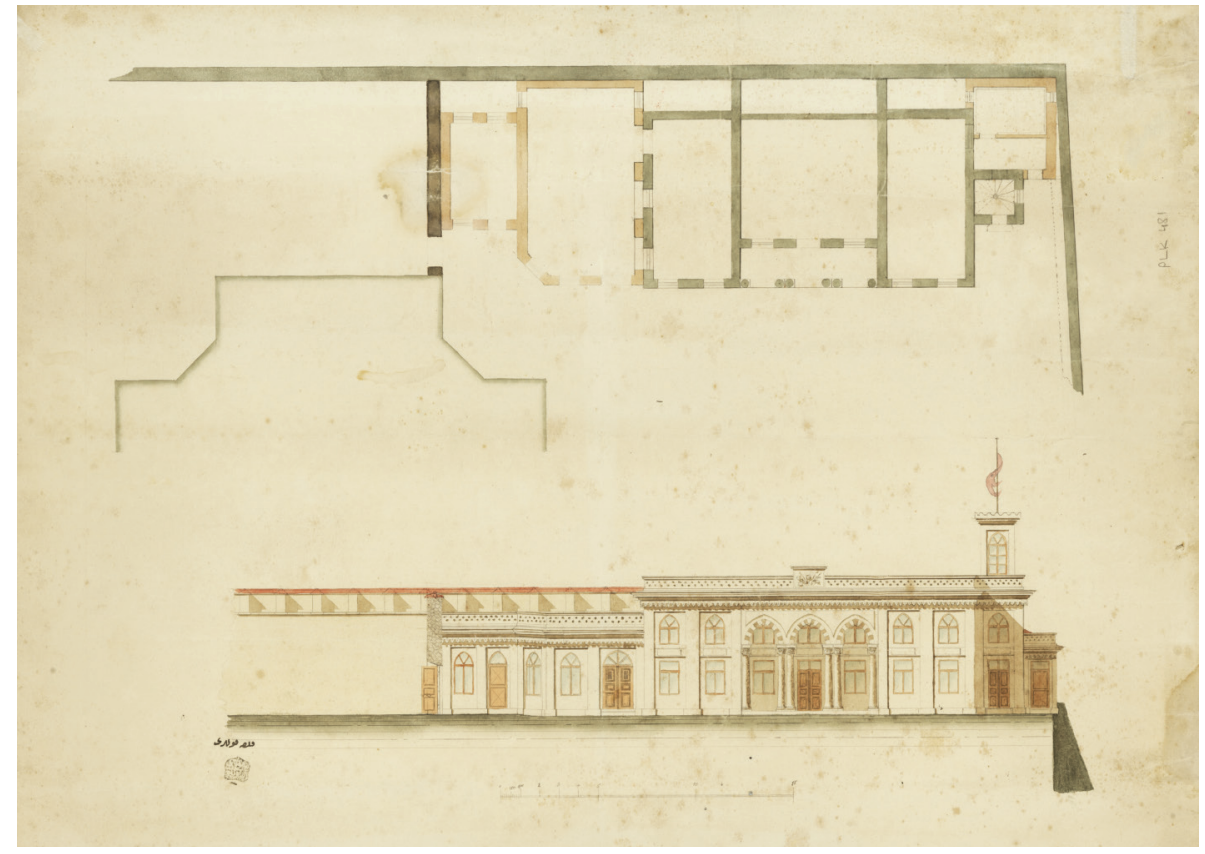

The police station, with its watchtower, coat of arms on its front façade, symmetrical configuration, pointed arches, moldings, arabesque details, ornamented façade, and its elaborated entrance, reflected the imperial architectural language of the Hamidian era, where historicist and orientalist forms were used to decorate the eclectic façades of the buildings. The photographs of various other police stations shown in the Abdülhamid II albums (fig. 6) prove that there was a shared a recognizable architectural vocabulary, defined by their castle-like aspects and dominating watchtowers with round windows. The standardized and noticeable architectural characteristics of these police stations reflected the surveillance and control mechanisms of the Hamidian regime as the guardians of the regime and emblems of the modernizing state.

Yet again, the life of this police station came to a conclusion during the Young Turk era. The Baghdad Pavilion police station was demolished by contractor İsmail Ağa in January 17, 1916.73 Only the foundation of the police station remained, which was discovered and photographed during the 1965-1966 restorations (fig. 19). A marble coat of arms, disassembled from the building during its demolition, is displayed today at the Topkapı Palace Museum in the second court (fig. 20). I suggest that the Young Turk government that overthrew Abdülhamid II in 1909, was eager to erase the memory and symbolic existence of the deposed sultan from this historically and politically noteworthy location. The historical and touristic characteristics of the Baghdad Pavilion were also emphasized during this period, which was a major destination for touristic tours and official visits to the Topkapı Palace. ${ }^{74}$ It is known that apart from Ottoman notables, royal visitors, such as German Emperor Wilhelm II and Austrian Emperor Karl I, spent time in the Baghdad Pavilion during their official visits to the Topkapi Palace. ${ }^{75}$ Thus, this recently built police station, which could have been seen as damaging the integrity of the Baghdad Pavilion and obstructing its magnificent view, might have been demolished to emphasize the historic and architectural wonders of this seventeenth-century royal pavilion and to obliterate the reminiscence of the Hamidian ancien régime (fig. 21). 

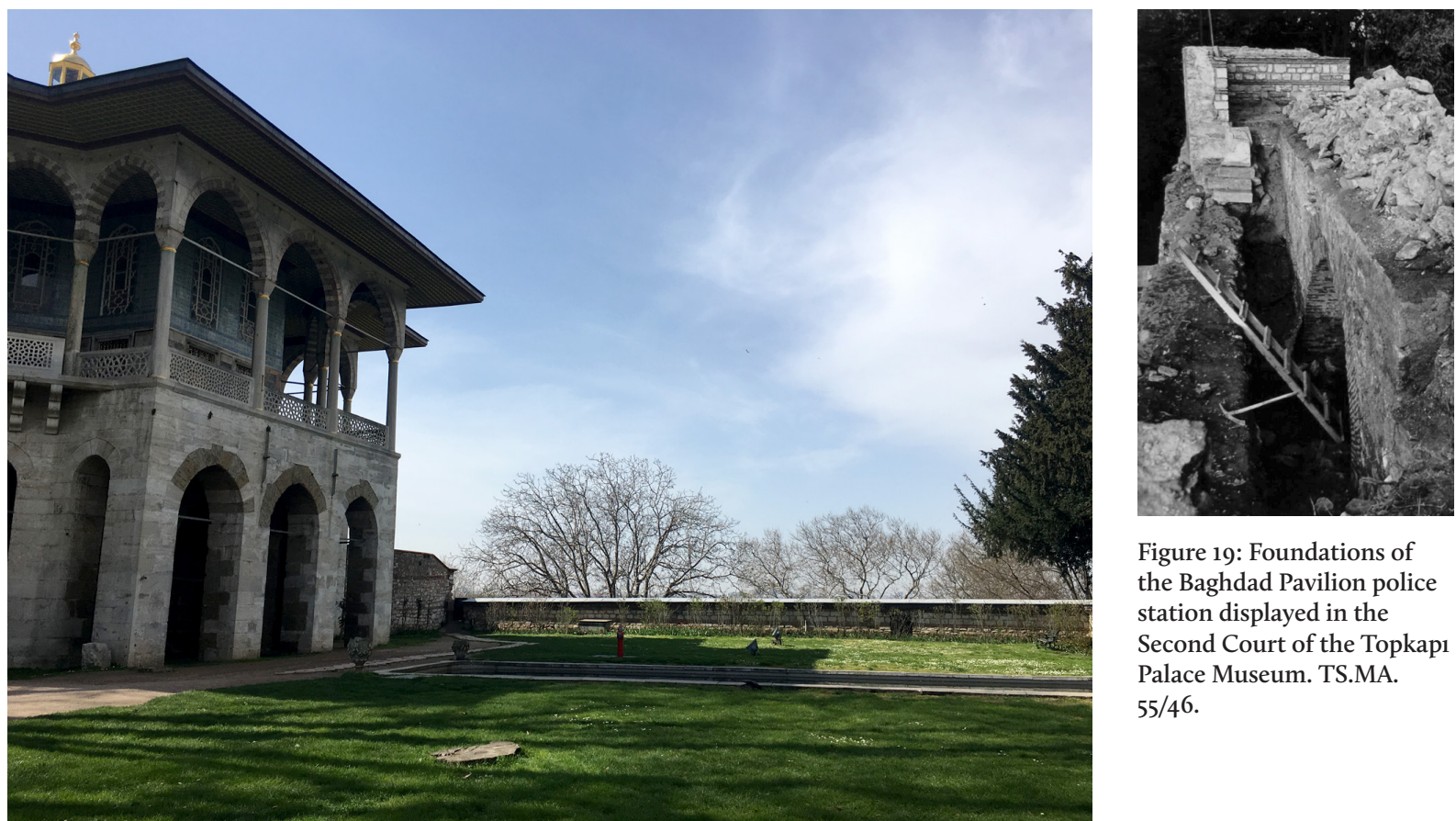

Figure 19: Foundations of the Baghdad Pavilion police station displayed in the Second Court of the Topkap 1 Palace Museum. TS.MA. $55 / 46$.

Figure 21: The location of the Baghdad Pavilion police station today. Nilay Özlü, 2016.

\section{Conclusion}

The Seraglio, Hamidiye and Baghdad Pavilion police stations, which were once part of the Historical Peninsula's silhouette and shaped the architectural landscape of the Seraglio Point, are now all gone (fig. 12-13). These remarkable buildings overlooking the Bosporus and the Golden Horn, alongside their distinguishing architectural features, marked the virtual presence of the sultan and his governance over his subjects. The surveillance of society through police forces reflected the mechanisms of the modernizing and centralizing state. Numerous police stations in the Topkapı Palace, in the city and in the empire, created a network of security and control mechanisms, securing the longevity of the Hamidian regime. Not only were the physicality of these three remarkable police stations, but also their names and symbolic existences erased from public memory. Therefore, this article has explored these long-forgotten structures and scrutinized their meaning within the mechanisms of the modernizing state.

The existence of ten police stations within the imperial walls of the Topkap 1 Palace during the late Ottoman era reflects a conscious choice and attempt to appropriate the Topkapi Palace and mark the palace of the Ottoman dynasty with Abdülhamid Il's ideological signature. Rather than building sultanic pleasure pavilions at the hanging gardens of the palace like his royal ancestors, Abdülhamid II preferred to manifest his imperial sovereignty with official and military buildings, confirming the empowered authoritarian regime. The police stations also manifest the symbolic, political, and historical significance of the Topkapi Palace sustained throughout the nineteenth century, as the royal complex became more accessible for foreign tourists and positioned as a major venue for dynastic and religious ceremonies.

Through the course of the nineteenth century, police stations appeared as architectural and symbolic statements of the regime and the modernizing state that aimed to re-establish the link to its own past. These small yet significant edifices manifested not only the visibility of the ruler but also the conquest of the urban landscape and the imperial past of the capital. These police stations, once located at prime locations in the royal complex as architectural representations of the regime, are now almost completely forgotten. This research compiled primary archival material, textual data, and unpublished visual documents regarding these police stations for analyzing the underlying implications of the existence and non-existence of these highly significant edifices, hoping to contribute to the architectural history and public memory of Istanbul.

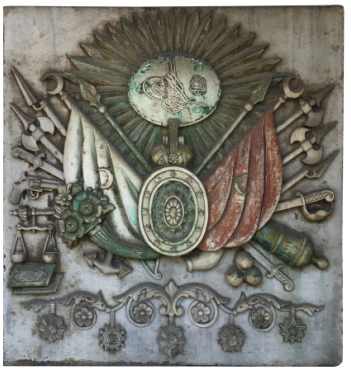

Figure 20: The coat of arms from the demolished Baghdad Pavilion police station displayed in the second court of the Topkapi Museum. Nilay Özlü, 2016. 


\section{Primary Sources}

Getty Archive Istanbul University Rare Works Library (İstanbul Üniversitesi Nadir Eserler Kitaplı̆̆ı) Yildız Albümü

Library of Congress Abdülhamid Il Albums

The Presidential Ottoman Archives (Cumhurbaşkanlığı Devlet Osmanlı Arşivleri) BOA, BEO. (Babıali Evrak Odası Evrakı) BOA, DH.ID. (Dahiliye Nezareti, İdare) BOA, HH. (Hazine-i Hassa) BOA PLK.p (Plan-Kroki) BOA, TS.MA (Topkapı Arşivi) BOA, Y.EE (Yıldız Esas Evrakı) BOA, Y.PRK.ASK. (Yildız Perakende, Askeri) BOA, Y.PRK.MYD. (Yıldız Perakende, Maiyyet, Erkan-1 Harbiye Dairesi Evrakı) BOA, Y.PRK.SGE. (Yıldız Perakende, Saray Görevlileri Evrakı)

Topkapı Palace Museum Archives (Topkapı Sarayı Müzesi Arşivi)

\section{Published Primary Sources}

Abdurrahman Şeref. "Topkapı Saray-ı Hümayunu." Tarih-i Osmani Encümeni Mecmuası 5 (1 Kanunievvel 1326 / 1910).

. “Topkapı Saray-1 Hümayunu.” Tarih-i Osmani Encümeni Mecmuası 6 (1 Şubat 1326 / 1911).

Ergin, Osman Nuri. Mecelle-i Umûr-ı Belediyye, Vol.2. Istanbul: İstanbul Büyükşehir Belediyesi Kültür İşleri Daire Başkanlığı, 1995 .

Gurlitt, Cornelius. Konstantinopel. Berlin: Marquardt \& Co., 1905.

Tarih-i Osmani Encümeni Mecmuast

Topuzlu, Cemil. İstibdat, Meşrutiyet, Cumhuriyet Devirlerinde 80 Yıllık Hatıralarım. Edited by Hüsrev Hâtemî and Aykut Kazancıgil. Istanbul: İşaret Yayınları, 2010.

Servet-i Fünun

\section{Secondary Sources}

Arslan, Necla. "Il. Mahmut ve Abdülmecit Dönemi Karakol Binaları." Uluslararası Dördüncü Türk Kültürü Kongresi Bildirileri, 69-84. Ankara: Atatürk Kültür Merkezi Yayınları, 1997.

Arslan Sevin, Necla. "XIX. Yüzyıl Osmanlı Başkentinde Polis Teşkilatı ve Karakol Binaları." TarihTarih. Accessed November 4, 2019. https://www.tarihtarih.com/?Syf $=26 \&$ Syz=352760\&/XIX.-Y\%C3\%BCzy\%C $4 \%$ B11-Osmanl\% $\mathrm{C}_{4} \% \mathrm{~B}_{1}-\mathrm{Ba} \% \mathrm{C}_{5} \%{ }_{9}$ Fkentinde-Polis-Te\% $\mathrm{C}_{5} \%{ }_{9}$ Fkilat\% $\mathrm{C}_{4} \% \mathrm{~B}_{1}$-ve-Karakol-Binalar\%C4\%B1-/-Do\%C3\%A7.-Dr.-Necla-Arslan-Sevin.

Çiftçi, Aynur. "19. Yüzyılda Osmanlı Devleti’nde Askeri Mimari ve İstanbul'da İnşa Edilen Askeri Yapılar.” PhD Diss., Yıldız Teknik Üniversitesi Fen Bilimleri Enstitüsü, 2004.

—_. "Karakol," Türkiye Diyanet Vakfi İslâm Ansiklopedisi. Vol. 24, 431-434. Istanbul: TDV İslâm Araştırmaları Merkezi, 1989.

Deringil, Selim. The Well Protected Domains. New York: I.B. Tauris \& Co., 1999.

Düzalan, Nurçe. "Demirkapı Kışlası'nın Tarihsel Gelişimi.” MA Thesis, İstanbul Teknik Üniversitesi, 2011.

Eldem, Edhem. Iftihar ve Imtiyaz: Osmanlı Nişan ve Madalyaları Tarihi. Istanbul: Osmanlı Bankası Arşiv ve Araştırma Merkezi, 2004.

Eldem, Sedad Hakkı, and Feridun Akozan, Topkapı Sarayı. İstanbul: Kültür ve Turizm Bakanlığı Eski Eserler ve Müzeler Genel Müdürlüğü, 1982.

Ergut, Ferdan. Modern Devlet ve Polis: Osmanlidan Cumhuriyet'e Toplumsal Denetimin Diyalektiği. Istanbul: Iletişim Yayınları, 2004.

Findley, Carter V. Bureaucratic Reform in the Ottoman Empire: The Sublime Porte, 1789-1922. Princeton: Princeton University Press, 1980. 
Foucault, Michel. Discipline and Punish: The Birth of the Prison. Translated by Alan Sheridan. New York: Pantheon Books, 1977.

Georgeon, François. Sultan Abdülhamid. Istanbul: Homer Kitabevi, 2006.

Gürol Öngören, Pelin. "Displaying Cultural Heritage, Defining Collective Identity: Museums from the Late Ottoman Empire to The Early Turkish Republic.” PhD Diss., Ortadoğu Teknik Üniversitesi, 2012.

İrez, Feryal, and Vahide Gezgör. "Milli Saraylar Arşivinde Yer Alan Belgeler Doğrultusunda Topkapı Sarayı Onarımları.” Milli Saraylar Arşivi, 18-45. Istanbul: TBMM Milli Saraylar Dairesi Başkanlığı Yayını, 1996.

Lévy-Aksu, Noémi. Osmanl İstanbul'unda asayiş, 1879-1909. Istanbul: İletişim, 2017.

Karacagil, Ö. Kürşad. “Alman İmparatoru İstanbul'da (1917).” Gazi Akademik Bakış 6, no. 12 (2013): 111-133.

Küçükalioğlu Özkılıç, Sema. 1894 Depremi ve Istanbul. Istanbul: İş Bankası Kültür Yayınları, 2015.

Müftüoğlu, Mustafa. Abdülhamid Ulu Hakan mı?. Kızıl Sultan mı?. Istanbul: Başak Yayınları, 2007.

Mustafa, Süheyla Nil. "Making of the Ottoman Policemen (1876-1918).” PhD Diss., Boğaziçi University, 2018.

“Yeni Osmanlı Polisi’nde Örgütsel Bağlllık ve Kültür." In Türk Polis Tarihinin Kökenleri, edited by Yücel Yiğit. Ankara: T.C. Polis Akademisi Başkanlığı, 2017.

- "Organizational Culture of the Ottoman Police." In Perspectives in Communication Studies: Festschrift in Honor of Prof. Dr. Ayseli Usluata, edited by Ayşe Binay Kurultay and Burcu Sabuncuoğlu 147-16o. Frankfurt Berlin Bern, Brusels, New York, Oxford, Vienna: Peter Lang Publishing, 2016.

Necipoğlu, Gülru. Architecture, Ceremonial, and Power : The Topkapı Palace in the Fifteenth and Sixteenth Centuries. New York; Cambridge: Architectural History Foundation; MIT Press, 1991.

Nişanyan, Sevan. "Karakol.” Nişanyan Sözlük. Accessed November 12, 2019. https://www.nisanyansozluk.com/?k=karakol.

Özbek, Nadir. "Policing the Countryside: Gendarmes of the Late-Nineteenth-Century Ottoman Empire (1876-1908)." International Journal of Middle East Studies 40, no. 1 (2008): 47-67.

Özcan, Abdülkadir. "Bostancı" Türkiye Diyanet Vakfı İslâm Ansiklopedisi, vol.6. Istanbul: TDV İslâm Araştırmaları Merkezi, 1989 .

Özgüven, Yekta. “II. Mahmud Dönemi İstanbulu’nda Kentsel-Fiziksel Kavrayışın Değişimi.” PhD Diss., Ylldız Teknik Üniversitesi, 2009.

Özlü, Nilay. "From Imperial Palace to Museum: The Topkapı Palace during the Long Nineteenth Century.” PhD Diss., Boğaziçi University, 2018.

Sakaoğlu, Necdet. The Imperial Palace with its History, Locations, Inscriptions and Memoirs: Topkapt Palace. Istanbul: Denizbank Publications, 2002.

Salkımll, Mehmet and Yılmaz Örsel. Osmanl Devleti Emniyet-i Umumiye 10 Nisan 1845: Türkiye Cumhuriyeti Polis Tarihi. Istanbul: Göksu Matbaacılık, 1990.

Schick, İrvin Cemil. "The Revival of Kufi Script during the Reign of Sultan Abdülhamid II." Calligraphy and Architecture in the Muslim World, edited by Mohammad Gharipour and Irvin Cemil Schick, 119138. Edinburgh: University of Edinburgh Press, 2013.

Shaw, Stanford J. and Ezel Kural Shaw. History of the Ottoman Empire and Modern Turkey. Reform, Revolution, and Republic: The Rise of Modern Turkey, 1808-1975, vol. 2. Cambridge: Cambridge University Press, 2005.

Shaw, Wendy M. K. Possessors and Possessed: Museums, Archeology, and the Visualization of History in the Late Ottoman Empire. Berkeley; Los Angeles; London: University of California Press, 2003.

Sönmez, Ali. “Zaptiye Teşkilatının Düzenlenmesi (1840-1869).” Ankara Üniversitesi Dil ve Tarih-Coğrafya Fakültesi Tarih Bölümü Tarih Araştırmaları Dergisi 25, no. 39 (2006): 199-219.

Stephanov, Darin. Ruler Visibility and Popular Belonging in the Ottoman Empire, 1808-1908. Edinburgh: Edinburgh University Press, 2018. University Press, 2018.

Tuğlacı, Pars. The Role of Balian Family in Ottoman Architecture. Istanbul: YÇK, 1990.

Uluengin, M. Bengü. "Secularizing Anatolia Tick by Tick: Clock Towers in the Ottoman Empire and the Turkish Republic.” International Journal of Middle Eastern Studies 42, no. 1 (2010): 17-36.

Uşaklıgil, Halit Ziya. Saray ve Ötesi. Istanbul: İnkılap ve Aka Kitabevleri, 1965.

Uzunçarşılı, İsmail Hakkı. Osmanlı Devletinin Saray Teşkilâtı. Ankara: Türk Tarih Kurumu Basımevi, 1984 .

Whetstone, Thomas, et al. "Police." Encyclopædia Britannica. Accessed November 12, 2019. https://www.britannica.com/topic/police.

Yerasimos, Stefanos. “Tanzimat'ın Kent Reformları Üzerine.” In Modernleşme Sürecinde Osmanlı Kentleri edited by Paul Dumont and François Georgeon, 1-18. Istanbul: Tarih Vakf1 Yurt Yayınları, 1996.

Yılmaz, Coşkun. II. Abdülhamid: Modernleşme Sürecinde Istanbul / Istanbul during the Modernization Process. Istanbul: İstanbul Avrupa Kültür Başkenti, 2010.

. II. Mahmud: Yeniden yapılanma sürecinde İstanbul / Istanbul in the Process of Being Rebuilt. Istanbul: İstanbul Avrupa Kültür Başkenti, 2010. 